Coalition On

Materials Emissions

Transparency

\title{
Comparison Between the IPCC Reporting Framework and Country Practice
}

JULY 2021

Jiarui Chen

\& Martin Dietrich Brauch

Columbia Center on Sustainable Investment 


\section{About}

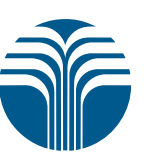

Columbia Center

on Sustainable Investment

A JOINT CENTER OF COLUMBIA LAW SCHOOL

AND THE EARTH INSTITUTE, COLUMBIA UNIVERSITY

The Columbia Center on Sustainable Investment is a leading applied research center and forum dedicated to the study, discussion and practice of sustainable international investment.

\section{M T T Tatation \\ Materials Emissions \\ Transparency}

The Coalition on Materials Emissions Transparency (COMET) is an initiative between the Columbia Center on Sustainable Investment (CCSI), the Payne Institute for Public Policy at the Colorado School of Mines, and RMI.

COMET accelerates supply chain decarbonization by enabling producers, consumer-facing companies, investors, and policy makers to better account for greenhouse gas (GHG) emissions throughout materials supply chains, in harmony with existing GHG accounting and disclosure methods and platforms. 
$\begin{array}{ll}\text { List of Acronyms and Abbreviations } & 4\end{array}$

$\begin{array}{ll}\text { Introduction } & 6\end{array}$

1 Background: Scopes and Approaches in Greenhouse Gas Reporting 6

1.1 Key Category Analysis

1.2 Greenhouse Gases to be Assessed

1.3 Sectoral Approach vs. Reference Approach

1.4 Gross Calorific Value (GCV) vs. Net Calorific Value (NCV)

2 Choice of Greenhouse Gas Calculation Methodology

2.1 Tier Methods and Country-Specific Methods

2.2 Germany

2.3 United States

2.4 Japan

2.5 Australia

2.6 Recommendations for Improvements for the IPCC Guidelines

3.1 Japan

3.2 United States

3.3 Australia

3.4 Germany

4 Different Results Depending on the Method Applied:

Case Study of Germany's Iron and Steel Industry

4.1 Country-Specific Method vs. Tier 2 Method vs. Tier 1 Method

4.2 Tier 3 Method vs. Tier 2 Method

5.1 Reporting Scope

5.2 Key Category Analysis

5.3 Methodology Choice

5.4 Quality Assurance and Quality Control

5.5 Summary

6 Findings and Recommendations

Appendix 1: IPCC Category Code 


\section{List of Acronyms and Abbreviations}

\begin{tabular}{|c|c|}
\hline BEU & Balance of Emissions Sources \\
\hline BGS & Federal Border Guard \\
\hline $\mathrm{BKB}$ & Brown Coal Briquettes \\
\hline BUR & Biennial Update Report \\
\hline CCSI & Columbia Center on Sustainable Investment \\
\hline $\mathrm{CH}_{4}$ & Methane \\
\hline $\mathrm{CO}$ & Carbon Monoxide \\
\hline $\mathrm{CO}_{2}$ & Carbon Dioxide \\
\hline COMET & Coalition on Materials Emissions Transparency \\
\hline CS & Country-Specific \\
\hline EF & Emission Factor \\
\hline ETF & Enhanced Transparency Framework \\
\hline GCV & Gross Calorific Value \\
\hline GHG & Greenhouse Gas \\
\hline HFCs & Hydrofluorocarbons \\
\hline IPCC & Intergovernmental Panel on Climate Change \\
\hline LPG & Liquefied Petroleum Gas \\
\hline LTO & Landing and Take-off Cycle \\
\hline $\mathrm{N}_{2} \mathrm{O}$ & Nitrous Oxide \\
\hline $\mathrm{NO}_{x}$ & Nitrogen Oxides \\
\hline NBS & National Bureau of Statistics of China \\
\hline NCV & Net Calorific Value \\
\hline NDC & Nationally Determined Contributions \\
\hline $\mathrm{NF}_{3}$ & Nitrogen Trifluoride \\
\hline NGI & National Gas Inventory \\
\hline NGL & Natural Gas Liquids \\
\hline NIR & National Inventory Report \\
\hline NMVOC & Non-Methane Volatile Organic Compound \\
\hline OECD & Organisation for Economic Co-operation and Development \\
\hline PFC & Perfluorinated Compound \\
\hline REDD+ & Reducing Emissions from Deforestation and Forest Degradation \\
\hline $\mathrm{SF}_{6}$ & Sulfur Hexafluoride \\
\hline $\mathrm{SO}_{2}$ & Sulfur Dioxide \\
\hline UNFCCC & United Nations Framework Convention on Climate Change \\
\hline
\end{tabular}




\section{Key Messages}

- The Intergovernmental Panel on Climate Change (IPCC) Guidelines for National Greenhouse Gas Inventories provide a recommended (but not mandatory) methodology for preparing National Inventory Reports (NIR) of greenhouse gas (GHG) emissions. All Annex I Parties to the United Nations Framework Convention on Climate Change (UNFCCC) (including developed countries and economies in transition) must submit a NIR every year. Non-Annex I Parties (most of which developing countries) in turn, are not required to submit NIRs, but must submit national inventories as part of their Biennial Update Reports (BURs).

- This study examines the NIRs of Australia, Germany, Japan, and the United States. Though all countries follow the IPCC Guidelines, their NIRs reflect different choices of GHG accounting methodologies and approaches (such as the bottom-up sectoral approach and the top-down reference approach), emission factors, and categories and gases reported. These choices, allowed under the IPCC Guidelines, result in significant differences in the $\mathrm{GHG}$ emissions reported.

- There often are significant differences between country-specific emission factors and the IPCC's default emission factors, which were calculated based on data collected in the early 1990s from the countries that were then members of the Organisation on Economic Co-operation and Development (OECD).

- The case study on the German iron and steel industry, applying the tier methods and the country-specific method under the IPCC Guidelines, reveals that the choice of different methods results in significantly different emissions calculated for the same categories.
- The case study on the national inventories included in China's BURs reveals that they partly applied the IPCC Guidelines for NIRs and lacked data continuity and periodic key category analysis. This result reinforces that various methodological choices tend to result in differences in GHG emissions reported across inventories of Annex I and Non-Annex I Parties.

- The widely diverging emissions reported across countries as a result of the good-faith application of the IPCC Guidelines illustrate the need for a harmonized GHG accounting framework, to improve the consistency and comparability of emissions inventories prepared by various countries.

- Recommendations for the IPCC, based on a mandate from the UNFCCC:

- Adopting a consolidated framework for GHG emissions accounting for Annex I and Non-Annex I Parties.

- Offering a forum for governments and their national GHG accounting bodies to collaborate in harmonizing emissions accounting, by sharing methods, data, and experience.

- Providing best practice for methodologies used in each category, based on country practice.

- Continuing to update default emission factors periodically, as most recently done in 2019, and for as many categories as feasible, so that emission factors are representative of the most recently calculated carbon intensity of fuels, as well as applicable to both Annex I and Non-Annex I Parties. 


\section{Introduction}

The 2006 Intergovernmental Panel on Climate Change (IPCC) Guidelines (IPCC 2008) for National Greenhouse Gas Inventories (IPCC Guidelines) provide a recommended (but not mandatory) methodology for preparing National Inventory Reports (NIR), which all Annex I Parties ${ }^{1}$ to the United Nations Framework Convention on Climate Change (UNFCCC) must submit every year (Romijn et al. 2019). In practice, however, many countries apply modified methodologies in their NIRs to reflect country-specific situations better. While helpful in addressing country specificities, those modified methodologies may result in emission data that is less standardized and therefore harder to compare and consolidate. Also, the IPCC recommends that countries adopt higher tier methods and use more granular data. Since different emissions categorized by the IPCC ${ }^{2}$ can be calculated by multiple methods, and the granularity and quality of country emissions databases vary, different countries adopt different granularity levels and tier methods (IPCC 2008).

The 160 Non-Annex I Parties to the UNFCCC (most of them developing countries) are not required to submit NIRs every year, but must submit Biennial Update Reports (BURs), including a national inventory report and information on mitigation actions, needs, and support received (Kainou 2016). Following the same IPCC Guidelines as NIRs, BURs are different from NIRs mainly in terms of reporting scope. The IPCC Guidelines require countries to report greenhouse gas (GHG) emissions in NIRs from 1980 to the latest reporting period, while for BURs they merely encourage countries to submit summary information tables of inventories for previous submission years. ${ }^{3}$ Besides the required BURs, more Non-Annex I Parties have been submitting NIRs and Technical Annexes on REDD+ in recent years (Romijn et al. 2019). In 2020, 23 Non-Annex I Parties submitted NIRs (UNFCCC 2020).

We recommend that the IPCC adopt, based on a mandate from the Conference of the Parties to the UNFCCC, a consolidated framework to indicate best practice for each emissions category. A consolidated framework would help unify the granularity levels and standards across all coun-

\footnotetext{
Annex I Parties include the industrialized countries that were members of the OECD (Organisation for Economic Co-operation and Development) in 1992, plus countries with economies in transition (the EIT Parties), including the Russian Federation, the Baltic States, and several Central and Eastern European States.

2 See the full list of IPCC categories in Appendix 1.

3 Other differences are addressed in the China case study in Section 5
}

tries' NIRs. It could also be extended to countries that have not adopted the IPCC Guidelines or published NIRs. Since an increasing number of Non-Annex I Parties are submitting NIRs to the UNFCCC, it is crucial to have a widely applicable framework that developing countries can also use.

A consolidated framework would also make it easier for countries to communicate their emissions reductions goals in their Nationally Determined Contributions (NDCs) under the Paris Agreement on Climate Change. With the Paris Agreement, countries established an enhanced transparency framework (ETF): starting in 2024, countries will report transparently on actions taken and progress in climate change mitigation, adaptation measures, and support provided or received. It also provides for international procedures for the review of the submitted NIRs. A standardized reporting framework for NIRs would comply with the requirement of transparency framework under Paris Agreement (Winkler et al. 2017).

To exemplify how a consolidated framework would work, after a background note on scopes and approaches in greenhouse gas reporting (section 1), we present the results of our empirical research on the NIRs of Australia, Germany, Japan, and the United States, focusing on the differences in the choice of methodology (section 2) and emission factors (section 3). Then we conduct a case study on the German iron and steel industry, exploring the differences in emission reporting under different methods (section 4). Finally, we study the case of China, which has submitted BURs but not yet published annual NIRs, to understand how the IPCC Guidelines could be applied to more countries (section 5). We outline our findings and recommendations in section 6 .

\section{$1 \quad$ Background: Scopes and Approaches in Greenhouse Gas Reporting}

Before reporting national emissions in line with the IPCC Guidelines, countries must identify the key categories to be reported (key category analysis) and the greenhouse gas to be included in each category (IPCC 2008). Countries must also choose emissions factors, for example, to convert fuels to emissions in category $1 \mathrm{~A}$ (Fuel Combustion Activities) and approaches to aggregate emissions. This section contrasts country-specific practices in reporting scopes and approaches with those recommended by the IPCC Guidelines. 
Table 1: IPCC Suggested Gases to Assessed (Excerpt)

\begin{tabular}{|l|c|c|c|c|}
\hline \multicolumn{2}{|c|}{ Category } & $\mathrm{CO}_{2}$ & $\mathrm{CH}_{4}$ & $\mathrm{~N}_{2} \mathrm{O}$ \\
\hline Fuel Combustion Activities & $1 \mathrm{~A}$ & $X$ & $X$ & $X$ \\
\hline Fugitive Emissions from Fuels & $1 \mathrm{~B}$ & $X$ & $X$ & \\
\hline Mineral Industry & $2 \mathrm{~A}$ & $X$ & & \\
\hline Enteric Fermentation & $3 \mathrm{~A} 1$ & & $X$ & \\
\hline Manure Management & $3 \mathrm{~A} 2$ & & $X$ & $X$ \\
\hline Forest Land; Grassland & $3 \mathrm{~B} 1,3$ & $X$ & & \\
\hline Cropland; Wetlands & $3 \mathrm{~B} 2,4$ & $X$ & & $X$ \\
\hline Settlements & $3 \mathrm{~B} 5$ & $X$ & & \\
\hline $\begin{array}{l}\text { Aggregate Sources and Non-CO } \\
\text { Emissions Sources on Land }\end{array}$ & $3 \mathrm{C}$ & $X$ & $X$ & $X$ \\
\hline Harvested Wood Products & $3 \mathrm{D} 1$ & $X$ & & \\
\hline
\end{tabular}

Source: Prepared by the authors based on 2006 IPCC Guidelines

for National Greenhouse Gas Inventories (IPCC 2008)

\subsection{Key Category Analysis}

The IPCC Guidelines recommend that countries run a key category ${ }^{4}$ analysis to determine which categories to report in their inventories and the method to be used in reporting (IPCC 2008). In general, for most greenhouse gas sources and sinks, the IPCC Guidelines recommend the adoption of higher tier (Tier 2 and 3) methods for key categories (IPCC 2008). The IPCC has classified the methodological approaches to calculate greenhouse gas inventories in three different Tiers, according to the quantity of information required and the degree of analytical complexity. The Tier 1 method employs the default[simplest] method described in the IPCC Guidelines and the default emission factors and other parameters provided by the IPCC. The Tier 2 method applies emission factors and other parameters that are specific to the country. Tier 3 method applies more details regarding to technology and equipment (IPCC 2008). The

\footnotetext{
4 "A category that is prioritized within the national inventory system because its estimate has a significant influence on a country's total inventory of greenhouse gases in terms of the absolute level, the trend or the uncertainty in emissions and removals." (IPCC, 2006)
}

IPCC Guidelines also provide category-specific decision trees and suggest methods for all categories. For source or sink categories that are considered non-key and for data that cannot be collected without significantly jeopardizing the resources for other key categories, the IPCC suggests choosing the Tier 1 method or model method presented in its Guidelines (IPCC 2008). All four countries reviewed here-Australia, Japan, Germany, and the United Statescompleted key category analysis and included the result in their NIR reports.

\subsection{Greenhouse Gases to be Assessed}

The choice of greenhouse gases to be included in the inventory can have a significant impact on the country's emissions profile. Table 1 presents IPCC's suggestions of greenhouse gases to be assessed in each category (see the full table in Annex 1).

Overall, there is a difference between the IPCC's suggestions for, and the countries' choice of, the greenhouse 
gases to be reported. Categories that are commonly missing from the four countries' NIRs are $\mathrm{CO}_{2}$ in categories 3B (Land), 3C (Aggregate Sources and Non- $\mathrm{CO}_{2}$ Emissions Sources on Land), and 3D (Other), and $\mathrm{N}_{2} \mathrm{O}$ in category $3 \mathrm{~A} 2$ (Manure Management). Some categories are missing by one or more countries (Details are shown in Appendix 3-6).

\subsection{Sectoral Approach vs. Reference Approach}

The reference approach is a top-down approach using a country's energy supply data to derive carbon emissions. The sectoral approach is a bottom-up approach using surveyed fuel consumption to derive $\mathrm{CO}_{2}$ emissions (IPCC 2008). The first difference between the two approaches lies in the energy data used to derive $\mathrm{CO}_{2}$ emissions as indicated in the definition. The reference approach provides no detailed information on how individual fuels are used in each sector. The second difference is that the reference approach includes emissions from non-energy uses. For example, in category $1 \mathrm{~A}$ (Fuel Combustion), some of the $\mathrm{CO}_{2}$ in the fuel is not combusted but will be emitted as fugitive emissions (Environmental Protection Agency (EPA) 2020).

Even if the IPCC recommends using the reference approach and requires all countries to submit emission estimation calculated by both approaches, the United States uses the sectoral approach in its NIRs. The United States has documented that the sectoral approach provides a more accurate assessment of $\mathrm{CO}_{2}$ emissions at the fuel level. For example, the reference approach estimates apparent consumption for crude oil. However, crude oil is not typically consumed directly but refined into other products. Thus, the United States estimates the various products' energy content resulting from crude oil refining rather than the energy content of various grades of crude oil. Besides, the United States uses sector-specific coal statistics in the sectoral approach (accounting for emissions from the residential, commercial, industrial, and transportation sectors) while the reference approach characterizes coal by rank (anthracite, bituminous, etc.). Also, liquefied petroleum gas (LPG) in the sectoral approach is a composite category composed of natural gas liquids (NGL) and LPG (EPA 2020).

As a result, emissions under the reference approach are $1.6 \%$ lower than the emissions under the sectoral approach for 2018 in the United States (EPA 2020). The most significant differences lie in lower estimates for the consumption of petroleum (3.4\%) and coal (1.7\%) under the reference approach, and higher estimates for natural gas consumption under the reference approach $(0.4 \%)$ in the United States (EPA 2020).

The improvement in accuracy is largely a result of the data collection techniques used in the United States, where there has been more emphasis on obtaining the detailed products-based information used in the sectoral approach than obtaining the aggregated energy flow data used in the reference approach (EPA 2020). The case of the United States indicates a better practice in acquiring energy consumption data for several fuel types. Based on this case, the information about crude oil refined products and sector-specific coal products should be considered when estimating energy content. However, because of the use of the sectoral approach, the United States does not address the non-energy use consumption.

\subsection{Gross Calorific Value (GCV) vs. Net Calorific Value (NCV)}

When converting a gas unit to an energy unit, using different calorific values may impact emissions data. The mismatch between the calorific value basis of activity data and emissions factors may also result in inconsistency.

The calorific value represents the amount of heat or energy in a given volume of gas. Gross calorific value (GCV) is the amount of heat released by the complete combustion of a unit of natural gas. Net calorific value (NCV) is determined by subtracting the heat of water vaporization from $\mathrm{GCV}$, which treats any $\mathrm{H}_{2} \mathrm{O}$ formed as a vapor. For coal and oil, the NCV is about 5\% lower than the GCV. For most natural and manufactured gas, the NCV is about $10 \%$ lower (IPCC 2008).

Where fuel characteristics (moisture, and hydrogen and oxygen contents) are known, the 2006 IPCC Guidelines give a more precise method to convert GCV to NCV data:

$$
\begin{gathered}
\mathrm{NCV}=\mathrm{GCV}-0.212 \mathrm{H}-0.0245 \mathrm{M}-0.008 \mathrm{Y} \\
\mathrm{M}-\text { Moisture, } \mathrm{H}-\text { Hydrogen, } \mathrm{Y}-\text { Oxygen, } \%
\end{gathered}
$$

Japan and the United States use GCV methods while Australia and Germany use NCV methods (IPCC 2008). The issue of using the GCV method is that the IPCC only provides 
default factors for NCV; only a set of Japan-specific GCV emissions factors are available.

\section{Choice of Greenhouse Gas Estimation Methodology}

This section focuses on the methods adopted by the four analyzed countries to calculate greenhouse gas emissions and compares them to the default methods proposed by IPCC Guidelines.

\subsection{Tier Methods and Country-Specific Methods}

The tier methods used in countries are generally adherent to the IPCC Guidelines. Taking Germany as an example, for 1A3a (Air Transport), the Tier 3 method is used, accounting for the annual flight mileages logged by the relevant individual aircraft types, broken down by national and international flights, and for the two operational states (landing and take-off cycle ${ }^{5}$, and cruise). For 1B2ai (Oil Exploration), the Tier 1 method is used due to the lack of pertinent measurements for the individual wells involved. The Tier 2 method is used for $2 \mathrm{Cl}$ (Iron and Steel Production) (Federal Republic of Germany 2020). Following the IPCC Guidelines, total emissions of iron and steel production are divided into three sub-categories and calculated using country-specific emissions factors.

The country-specific methods are different from the IPCC tier methods in terms of data collection granularity, calculation methods, country-specific disaggregation, and emissions factors. For example, the country-specific method defined in Germany's NIR is different from the Tier 2 and 3 methods in the IPCC Guidelines. First, Germany applies a methodology to calculate total emissions by using a country-specific survey or method to collect the activity data, calculating the country-specific granularity, and applying country-specific emissions factors. For example, to adjust for the specificities of the German iron and steel industry, Germany uses activity data from the Bundesgrenzschutz (BGS) ${ }^{6}$ for sintering plants, blast furnaces, basic oxygen furnaces (converters), and rolling mills, and to further disaggregate electricity data in the steel sector (Federal Republic of Germany 2020). Second, the emissions factors used in the country-specific method are different from those used in the IPCC Tier 2 method for the same fuels (Juhrich 2017). Emission factors used under Germany's country-specific method are also industry-specific.

In general, the IPCC suggests using high tier (2 or 3 ) methods (IPCC 2008). In practice, the methods used in different categories in different countries depend on: 1) whether the category is a key category; 2) whether the data collected is sufficient for the application of the higher tier method; 3) whether a lower tier methodology specified in the IPCC Guidelines can sufficiently reflect accurate emissions in the category.

\subsection{Germany}

Regarding the types of gases assessed, Germany is the only country among the four analyzed that reports nonmethane volatile organic compounds (NMVOC) and $\mathrm{SO}_{2}$.

Comparing the methodology used in Germany with that of the three other countries analyzed (see Table 2):

1) Emissions in $1 \mathrm{~A}$ (Fuel Combustion Activities) are mainly calculated by Germany's country-specific method while under IPCC tier methods in other countries. In Germany, the activity data for stationary combustion are calculated in the "Balance of Emissions Sources" (BEU) model developed by the Federal Environment Agency. Besides being categorized by fuels, the BEU model takes into account the types of facilities, plants with different technical principles, and regional peculiarities. Overall, the granularity of emissions data in $1 \mathrm{~A}$ is higher in Germany than in the other countries (Federal Republic of Germany 2020).

2) Emissions in 1B (Fugitive Emissions from Fuels) are mainly calculated using tier methods in Germany while using country-specific methods in the other countries. Overall the granularity of emissions data in 1B in Germany is lower than in the other countries (Federal Republic of Germany 2020).

\footnotetext{
5 It covers four modes of engine operation, namely idle, approach, climb out and take-off, each of which is associated with a specific engine thrust setting and a time in mode.

6 Bundesgrenzschutz, the Germany agency providing iron and steel industry activity data.
} 
3) $\mathrm{CO}_{2}$ emissions in 4B (Biological Treatment of Solid Waste) and 4C (Incineration and Open Burning of Waste) are calculated by Tier 2 methods in Germany but by Tier 3 methods in other countries. Overall, the granularity of emissions data in $4 \mathrm{~B}$ and $4 \mathrm{C}$ is lower in Germany than in the other countries.

To summarize, Germany's approach to methodology selection indicates several best practices for other countries and the IPCC:

1) For $1 \mathrm{~A}$ (Fuel Combustion Activities), the main contributors to greenhouse gas emissions, we recommend that countries should develop country-specific methods to improve reporting accuracy. However, for consistency, countries should document the difference between their country-specific method and IPCC tier methods, conduct verification, and provide the emission results calculated by using IPCC Tier methods.

2) Germany should consider further increasing the granularity of reporting $\mathrm{CO}_{2}$ emissions for $4 \mathrm{~B}$ (Biological Treatment of Solid Waste) and 4C (Incineration and Open Burning of Waste).

\section{$2.3 \quad$ United States}

$\mathrm{CH}_{4}$ and $\mathrm{N} 2 \mathrm{O}$ emissions in $1 \mathrm{~A}$ (Fuel Combustion Activities) are calculated by the Tier 1 method in the United States while calculated by Tier 2 and 3 methods in other countries (see Table 3). The United States could therefore increase the granularity of reporting of $\mathrm{CH}_{4}$ and $\mathrm{N}_{2} \mathrm{O}$ emissions for 1A (EPA 2020).

Table 2: Methodologies Used in Germany (Excerpt)

\begin{tabular}{|c|c|c|c|c|c|c|c|c|c|c|c|}
\hline Categories & $\mathrm{CO}_{2}$ & $\mathrm{CH}_{4}$ & $\mathrm{~N}_{2} \mathrm{O}$ & $\mathrm{NO}_{x}$ & $\mathrm{CO}$ & NMVOC & $\mathrm{SO}_{2}$ & HFCs & $\mathrm{SF}_{6}$ & PFC & $\mathrm{NF}_{3}$ \\
\hline $1 \mathrm{~A} 1$ & CS & 2 & 2 & $\mathrm{CS}$ & CS & CS & $\mathrm{CS}$ & & & & \\
\hline $1 \mathrm{~A} 2$ & $\mathrm{CS}$ & CS & $\mathrm{CS}$ & CS & CS & $\mathrm{CS}$ & $\mathrm{CS}$ & & & & \\
\hline 1A3a & 3 & 3 & 3 & 3 & 3 & 3 & 1 & & & & \\
\hline $1 \mathrm{~A} 3 \mathrm{~b}$ & 2 & 3 & 3 & 3 & 3 & 3 & 3 & & & & \\
\hline $1 A 3 c, d$ & 2 & 2 & 2 & 2 & 2 & 2 & 2 & & & & \\
\hline 1A3e & CS & 2 & 2 & 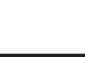 & 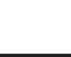 & 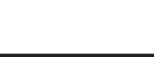 & 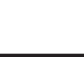 & & & & \\
\hline $1 \mathrm{~A} 4$ & $\mathrm{CS}$ & 2 & 2 & 2 & 2 & 2 & 2 & & & & \\
\hline $1 \mathrm{A5a}$ & $\mathrm{CS}$ & 3 & 3 & . & 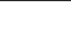 & & & & & & \\
\hline $1 \mathrm{~A} 5 \mathrm{~b}$ & CS & 3 & 3 & 3 & 3 & 3 & 3 & & & & \\
\hline 1B2ai & 1 & 1 & & & & 2 & & & & & \\
\hline 1B2aii & 2 & 2 & & & & 2 & & & & & \\
\hline 1B2aiii & & 2 & & & & 2 & & & & & \\
\hline 1B2aiv & 2 & 2 & & 2 & 2 & 2 & 2 & & & & \\
\hline 1B2av & & . & & & & 2 & & & & & \\
\hline 1B2bii & 2 & 2 & & & & 2 & & & & & \\
\hline 1B2biii & 2 & 2 & & & 2 & 2 & 2 & & & & \\
\hline 1B2biv (transmission) & & 3 & & & & & & & & & \\
\hline 1B2biv (storage) & & 2 & & & & & & & & & \\
\hline $1 \mathrm{~B} 2 \mathrm{C}$ & 2 & 2 & 2 & & & 2 & & & & & \\
\hline $4 \mathrm{~B}$ & 2 & 2 & 2 & & & & & & & & \\
\hline $4 C$ & 2 & 2 & 2 & & & & & & & & \\
\hline
\end{tabular}

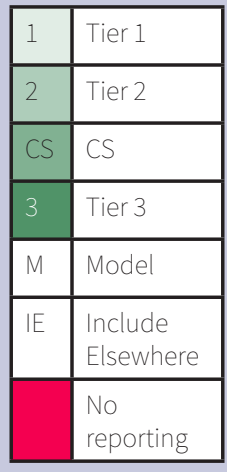

Source: Prepared by the authors based on National Inventory Report for the German Greenhouse Gas Inventory 1990 - 2018 (Federal Republic of Germany 2020) 
Table 3: Methodologies Used in the United States (Excerpt)

\begin{tabular}{|c|c|c|c|c|c|c|c|c|c|c|c|}
\hline Categories & $\mathrm{CO}_{2}$ & $\mathrm{CH}_{4}$ & $\mathrm{~N}_{2} \mathrm{O}$ & $\mathrm{NO}_{2}$ & $\mathrm{CO}$ & $\mathrm{NMVOC}$ & $\mathrm{SO}_{2}$ & $\mathrm{HFCS}$ & $\mathrm{SF}_{6}$ & $\mathrm{PFC}$ & $\mathrm{NF}_{3}$ \\
\hline $1 \mathrm{~A}$ & 2 & 1 & 1 & & & & & & & & \\
\hline $1 \mathrm{~A} 3 \mathrm{a}$ & 3 & 1 & 1 & & & & & & & & \\
\hline $1 \mathrm{~A} 5$ & $\mathrm{CS}$ & $\mathrm{M}$ & $\mathrm{M}$ & & & & & & & & \\
\hline $2 \mathrm{~B} 2$ & $\mathrm{CS}$ & $\mathrm{CS}$ & $\mathrm{CS}$ & & & & & & & & \\
\hline $2 \mathrm{~A} 3$ & 2 & & & & & & & & & & \\
\hline $2 \mathrm{~B} 1$ & $\mathrm{CS}$ & & & & & & & & & & \\
\hline $2 \mathrm{~B} 2,3$ & & & 3 & & & & & & & & \\
\hline $2 \mathrm{~B} 5$ & 1 & 1 & & & & & & & & & \\
\hline $2 \mathrm{~B} 6$ & 1 & & & & & & & & & & \\
\hline $2 \mathrm{~B} 7$ & 1 & & & & & & & & & & \\
\hline $2 \mathrm{~B} 8$ & 1 & 1 & & & & & & & & & \\
\hline $2 \mathrm{~B} 9$ & 3 & & & & & & & & & & \\
\hline $2 \mathrm{C} 1$ & $\mathrm{CS}$ & $\mathrm{CS}$ & & & & & & & & & \\
\hline $2 \mathrm{C} 2$ & 1 & 1 & & & & & & & & & \\
\hline $2 \mathrm{C} 3$ & $\mathrm{CS}$ & & & & & & & & & $\mathrm{CS}$ & \\
\hline $2 \mathrm{C} 4$ & $\mathrm{CS}$ & & & & & & & $\mathrm{CS}$ & $\mathrm{CS}$ & & \\
\hline $2 \mathrm{C} 5$ & 1 & & & & & & & & & & \\
\hline $2 \mathrm{C} 6$ & 1 & & & & & & & & & & \\
\hline $2 \mathrm{D}$ & & & & & & & & & & & \\
\hline $2 \mathrm{E}$ & & & $\mathrm{CS}$ & & & & & $\mathrm{CS}$ & $\mathrm{CS}$ & $\mathrm{CS}$ & $\mathrm{CS}$ \\
\hline $2 \mathrm{~F}$ & & & & & & & & $\mathrm{CS}$ & & $\mathrm{CS}$ & \\
\hline $2 \mathrm{G}$ & & & $\mathrm{CS}$ & & & & & & $\mathrm{CS}$ & & \\
\hline $3 \mathrm{~A}$ & & 2 & & & & & & & & & \\
\hline $3 \mathrm{~B}$ & & 2 & 2 & & & & & & & & \\
\hline $3 \mathrm{C}$ & & 3 & & & & & & & & & \\
\hline $3 \mathrm{D}$ & & & 3 & & & & & & & & \\
\hline $3 \mathrm{G}$ & 2 & & & & & & & & & & \\
\hline $3 \mathrm{H}$ & 1 & & & & & & & & & & \\
\hline $3 \mathrm{~F}$ & & 2 & 2 & 2 & 2 & & & & & & \\
\hline
\end{tabular}

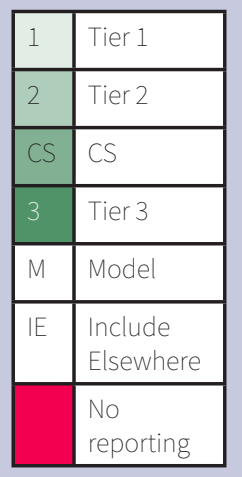

Source: Prepared by the authors based on Inventory of

U.S. Greenhouse Gas Emissions and Sinks 1990-2018 (EPA 2020) 


\subsection{Japan}

Japan adopts the most granular tier methods in emissions reporting among the four countries analyzed (see Table 4). Also, a set of IPCC GCV default factors is specific to Japan. Kazunari Kainou calculated Japanese GCV and Carbon Emission Factor upon the request of Japanese Ministries by using real measured physical and chemical data and calorific value in 2013 and submitted to IPCC database (Kainou 2016). Therefore, the granularity of emissions in 1B (Fugitive Emissions from Fuels), calculated using the Tier 1 method, is theoretically the same as using the Tier 2 method.
Comparing the methodology used in Japan with other countries:

1) $\mathrm{CH}_{4}$ and $\mathrm{N}_{2} \mathrm{O}$ emissions in $\mathrm{AA}$ (Fuel Combustion Activities) are calculated by the Tier 3 method, which is the most granular among the four countries.

2) $\mathrm{HFCs}, \mathrm{SF}_{6}, \mathrm{PFC}$, and $\mathrm{NF}_{3}$ emissions in $2 \mathrm{~B}$ (Chemical Industry) are calculated using the Tier 3 method, which is the most granular among the four countries.

3) Japan reports HFCS, $\mathrm{SF}_{6}$, and PFC emissions for 2C (Metal Industry), which are not reported in other countries.

Table 4: Methodologies Used in Japan (Excerpt)

\begin{tabular}{|c|c|c|c|c|c|c|c|c|c|c|c|}
\hline Categories & $\mathrm{CO}_{2}$ & $\mathrm{CH}_{4}$ & $\mathrm{~N}_{2} \mathrm{O}$ & $\mathrm{NO}_{x}$ & $\mathrm{CO}$ & $\mathrm{NMVOC}$ & $\mathrm{SO}_{2}$ & $\mathrm{HFCS}$ & $\mathrm{SF}_{6}$ & $\mathrm{PFC}$ & $\mathrm{NF}_{3}$ \\
\hline $1 \mathrm{~A}$ & 2 & 3 & 3 & & & & & & & & \\
\hline $1 \mathrm{~B} 1$ & $\mathrm{CS}$ & 3 & & & & & & & & & \\
\hline $1 \mathrm{~B} 2$ & $\mathrm{CS}$ & $\mathrm{CS}$ & 1 & & & & & & & & \\
\hline $2 \mathrm{~A}$ & 2 & & & & & & & & & & \\
\hline $2 \mathrm{~B}$ & 3 & $\mathrm{CS}$ & 3 & & & & & 3 & 3 & 3 & 3 \\
\hline $2 \mathrm{C}$ & & $\mathrm{CS}$ & & & & & & $\mathrm{CS}$ & 2 & 2 & \\
\hline $2 \mathrm{D}$ & 2 & & & & & & & & & & \\
\hline $2 \mathrm{~F}$ & & & & & & & & 2 & 2 & 2 & 2 \\
\hline $2 \mathrm{~F}$ & & & & & & & & $\mathrm{CS}$ & & $\mathrm{CS}$ & \\
\hline $2 \mathrm{H}$ & $\mathrm{CS}$ & & & & & & & & & & \\
\hline $3 \mathrm{~A} 2,3,4$ & & 1 & & & & & & & & & \\
\hline $3 \mathrm{~A} 1$ & & 2 & & & & & & & & & \\
\hline $3 \mathrm{~B} 1,3$ & & $\mathrm{CS}$ & & & & & & & & & \\
\hline $3 \mathrm{~B} 2,4$ & & 1 & 1 & & & & & & & & \\
\hline $3 \mathrm{~B} 5$ & & & 2 & & & & & & & & \\
\hline $3 \mathrm{C}$ & & 3 & & & & & & & & & \\
\hline $3 \mathrm{D}$ & & & $\mathrm{CS}$ & & & & & & & & \\
\hline $3 \mathrm{Da} 1,2$ & & & 2 & & & & & & & & \\
\hline $3 \mathrm{G}$ & 1 & & & & & & & & & & \\
\hline $3 \mathrm{H}$ & 1 & & & & & & & & & & \\
\hline $3 \mathrm{~F}$ & & 1 & 1 & & & & & & & & \\
\hline
\end{tabular}

\begin{tabular}{|l|l|}
\hline 1 & Tier 1 \\
\hline 2 & Tier 2 \\
\hline CS & CS \\
\hline 3 & Tier 3 \\
\hline M & Model \\
\hline IE & \begin{tabular}{l} 
Include \\
Elsewhere \\
\hline
\end{tabular} \\
$\begin{array}{l}\text { No } \\
\text { reporting }\end{array}$ \\
\hline
\end{tabular}

Source: Prepared by the authors based on National Greenhouse Gas Inventory Report of Japan (Greenhouse Gas Inventory Office of Japan 2020) 
To summarize, Japan's approach to methodology selection indicates several best practices for other countries and the IPCC:

1) Countries could upgrade to Tier 3 the methods used for $\mathrm{CH}_{4}$ and $\mathrm{N}_{2} \mathrm{O}$ emissions in $1 \mathrm{~A}$ (Fuel Combustion Activities), and HFCS, SF, PFC and NF3 emissions in 2B (Chemical Industry).

2) Countries could report HFCs, $\mathrm{SF}_{6}$, and PFC emissions for 2C (Metal Industry).

\subsection{Australia}

Australia fully follows the IPCC Guidelines and adopts tier methods in most categories (see Table 5) (Department of
Industry, Science, Energy and Resources (DISER) 2020). However, there is a trade-off between standardization and reflecting country-specific situations. Following the default process may also result in the inaccuracy of data reporting.

\subsection{Recommendations for Improvements for the IPCC Guidelines}

In light of the practices of the four countries analyzed, presented above, the IPCC could improve its Guidelines by providing guidance on setting up country-specific methods for 1B (Fugitive Emissions from Fuels).

Table 5: Methodologies Used in Australia (Excerpt)

\begin{tabular}{|c|c|c|c|c|c|c|c|c|c|c|c|}
\hline Categories & $\mathrm{CO}_{2}$ & $\mathrm{CH}_{4}$ & $\mathrm{~N}_{2} \mathrm{O}$ & $\mathrm{NO}_{\mathrm{x}}$ & $\mathrm{CO}$ & $\mathrm{NMVOC}$ & $\mathrm{SO}_{2}$ & $\mathrm{HFCS}$ & $\mathrm{SF}_{6}$ & $\mathrm{PFC}$ & $\mathrm{NF}_{3}$ \\
\hline $1 \mathrm{~A}$ & 2 & 2 & 2 & & & & & & & & \\
\hline $1 \mathrm{~A} 3 \mathrm{a}$ & 2 & 2 & 2 & 1 & 1 & 1 & & & & & \\
\hline $1 \mathrm{~A} 3 \mathrm{~b}$ & 2 & 3 & 3 & & & & & & & & \\
\hline $1 \mathrm{~A} 3 \mathrm{c}$ & 2 & 1 & 1 & 2 & 2 & 2 & & & & & \\
\hline $1 \mathrm{~A} 3 \mathrm{e}$ & 2 & 1 & 1 & & & & & & & & \\
\hline $1 \mathrm{~A} 5 \mathrm{~b}$ & 1 & 2 & 2 & & & & & & & & \\
\hline $1 \mathrm{~B} 1 \mathrm{a}$ & 3 & 3 & & & & & & & & & \\
\hline $1 \mathrm{~B} 2$ & $\mathrm{CS}$ & $\mathrm{CS}$ & $\mathrm{CS}$ & & & & & & & & \\
\hline $2 \mathrm{~A}$ & 2 & & & & & & & & & & \\
\hline $2 \mathrm{~B} 1$ & 3 & & & & & & & & & & \\
\hline $2 \mathrm{~B} 2$ & & & 3 & & & & & & & & \\
\hline $2 \mathrm{~B} 5$ & 2 & & & & & & & & & & \\
\hline $2 \mathrm{~B} 6$ & 2 & & & & & & & & & & \\
\hline $2 \mathrm{~B} 7$ & 3 & & & & & & & & & & \\
\hline $2 \mathrm{~B} 8$ & & 2 & & & & & & & & & \\
\hline $2 \mathrm{C} 1$ & 3 & 2 & 2 & & & & & & & & \\
\hline $2 \mathrm{C} 2$ & 2 & & & & & & & & & & \\
\hline $2 \mathrm{C} 3$ & 3 & & & & & & & & & 3 & \\
\hline $2 \mathrm{C} 4$ & & & & & & & & & 2 & & \\
\hline $2 \mathrm{C} 56$ & 2 & 2 & 2 & & & & & & & & \\
\hline $2 \mathrm{D} 7$ & 2 & 2 & 2 & & & & & & & & \\
\hline $2 \mathrm{D} 1$ & 2 & & & & & & & & & & \\
\hline $2 \mathrm{~F}$ & & & & & & & & $\mathrm{M}$ & 2 & & \\
\hline $2 \mathrm{G}$ & & & 2 & & & & & & & & \\
\hline $2 \mathrm{H} 2$ & $\mathrm{CS}$ & & & & & & & & & & \\
\hline
\end{tabular}




\section{Choice of Emissions Factors}

The IPCC's default emissions factors database was initially developed in 2006. Most of the carbon emission factors are calculated in Energy Balances of OECD Countries (1990-1991) and several other studies (IPCC 2008). IPCC's database of default emissions factors presents the following drawbacks:

1) The emissions factors were calculated based on data from the 1990s. The composition, quality, and geographical distribution of the fuels have changed since.

2) The emissions factors are calculated based on OECD countries. On the one hand, some countries have joined OECD after 1996; on the other, the default emissions factors may not accurately reflect non-OECD countries' emissions.

3) GCV carbon emission factors are only applicable to Japan.

In this section we compare IPCC default emissions factors with country-specific emissions factors, examine the need to apply country-specific emissions factors, and highlight where IPCC default emissions factors are highly different from emissions factors and would therefore merit updating.

\subsection{Japan}

Table 6 presents a comparison between Japan's countryspecific emission factors for each fuel type and IPCC default emission factors (Greenhouse Gas Inventory Office of Japan 2020). Japan converts fuel units to heat by GCV. The gaps between the (higher) IPCC emissions factors and the (lower) country-specific emissions factors of Orimulsion, ${ }^{7}$ refinery feedstocks, sub-bituminous coal, brown coal briquettes (BKB) and patent fuel, and solid biomass mainly result from the lack of GCV default factors.

From 1990 to 2018, the average $\mathrm{CO}_{2}$ emissions of Orimulsion, refinery feedstocks, sub-bituminous coal, BKB and patent fuel, and solid biomass are $486.27 \mathrm{kt}, 804.20$ kt, 6,638.99 kt, 0 kt, 26,443.63 kt respectively, accounting for $2.93 \%$ of Japan's total $\mathrm{CO}_{2}$ emissions (Greenhouse Gas Inventory Office of Japan 2020). Because of the differences between IPCC and country-specific emissions factors for these five fuels, the total emissions reported by Japan are $0.26 \%$ higher when using IPCC emissions factors than when using country-specific ones. 
Table 6: Japan Emission Factors vs. IPCC Default

\begin{tabular}{|c|c|c|c|c|c|c|}
\hline \multirow{3}{*}{ FUEL TYPES } & & & $\begin{array}{l}\text { Carbon Emission } \\
\text { Factor }\end{array}$ & \multirow{3}{*}{ Note } & $\begin{array}{c}\text { Carbon Emission } \\
\text { Factor } \\
\end{array}$ & \multirow{3}{*}{$\begin{array}{c}\text { Difference } \\
\end{array}$} \\
\hline & & & $\frac{t C / T J}{10 \rho C^{*}}$ & & $\mathrm{tC} / \mathrm{TJ}$ & \\
\hline & & & $\mathrm{IPCC}^{\star}$ & & Average & \\
\hline \multirow[t]{17}{*}{ Liquid fossil } & \multirow{3}{*}{$\begin{array}{l}\text { Primary } \\
\text { fuels }\end{array}$} & Crude oil & 19.00 & & 19.05 & $0 \%$ \\
\hline & & Orimulsion & 22.00 & & 19.96 & $10 \%$ \\
\hline & & Natural gas liquids & 18.26 & & 17.73 & $3 \%$ \\
\hline & \multirow{14}{*}{$\begin{array}{l}\text { Secondary } \\
\text { fuels }\end{array}$} & Gasoline & 18.72 & 1) & 18.38 & $2 \%$ \\
\hline & & Jet kerosene & 18.60 & & 18.37 & $1 \%$ \\
\hline & & Other kerosene & 18.71 & 2) & 18.55 & $1 \%$ \\
\hline & & Shale oil & & & & \\
\hline & & Gas/diesel oil & 18.79 & 1) & 18.74 & $0 \%$ \\
\hline & & Residual fuel oil & 20.17 & 1) & 19.73 & $2 \%$ \\
\hline & & $\begin{array}{l}\text { Liquefied petroleum gases } \\
\text { (LPG) }\end{array}$ & 16.38 & 1) & 16.47 & $-1 \%$ \\
\hline & & Ethane & & & & \\
\hline & & Naphtha & 18.63 & 1) & 18.27 & $2 \%$ \\
\hline & & Bitumen & 20.41 & 1) & 20.69 & $-1 \%$ \\
\hline & & Lubricants & 19.89 & 1) & 19.36 & $3 \%$ \\
\hline & & Petroleum coke & 24.5 & 1) & 25.17 & $-3 \%$ \\
\hline & & Refinery feedstocks & 20.00 & & 18.88 & $6 \%$ \\
\hline & & Other oil & 20.17 & 1) & 14.21 & $42 \%$ \\
\hline \multirow[t]{9}{*}{ Solid fossil } & \multirow{6}{*}{$\begin{array}{l}\text { Primary } \\
\text { fuels }\end{array}$} & Anthracite & 25.92 & 1) & 25.56 & $1 \%$ \\
\hline & & Coking coal & 24.42 & 1) & 24.49 & $0 \%$ \\
\hline & & Other bituminous coal & 24.74 & 1) & 24.65 & $0 \%$ \\
\hline & & Sub-bituminous coal & 26.20 & & 24.68 & $6 \%$ \\
\hline & & Lignite & 26.82 & 1) & & \\
\hline & & Oil shale and tar sand & & & & \\
\hline & \multirow{3}{*}{$\begin{array}{l}\text { Secondary } \\
\text { fuels }\end{array}$} & BKB and patent fuel & 25.80 & & 28.67 & $-10 \%$ \\
\hline & & Coke oven/gas coke & 30.22 & 1) & 29.54 & $2 \%$ \\
\hline & & Coal tar & & 3) & 20.90 & \\
\hline \multicolumn{2}{|l|}{ Gaseous fossil } & Natural gas (dry) & 13.95 & 1) & 13.94 & $0 \%$ \\
\hline \multicolumn{3}{|c|}{ Waste (non-biomass fraction) } & & 3) & 10.36 & \\
\hline \multirow{4}{*}{\multicolumn{2}{|c|}{ Biomass total }} & Solid biomass & 29.90 & & 27.31 & $9 \%$ \\
\hline & & Liquid biomass & & 3) & 17.29 & \\
\hline & & Gas biomass & & 3) & 12.59 & \\
\hline & & $\begin{array}{l}\text { Other non-fossil fuels } \\
\text { (biogenic waste) }\end{array}$ & & 3) & 146.68 & \\
\hline \multicolumn{7}{|c|}{$\begin{array}{l}\text { * Country-specific EF. If there's country-specific EF in IPCC database other than default, NCV and GCV value, will adopt the country-specific } \\
\text { one } \\
\text { 1) IPCC GCV/NCV EF just for Japan } \\
\text { 2) IPCC default EF is not applicable } \\
\text { 3) IPCC no default carbon emission factor for this fuel }\end{array}$} \\
\hline
\end{tabular}

Source: Prepared by the authors based on National Greenhouse Gas Inventory Report of Japan

(Greenhouse Gas Inventory Office of Japan 2020) 


\subsection{United States}

Table 7 presents a comparison between the United States country-specific emission factors for each fuel type and IPCC default emission factors. The United States converts fuel units to heat by GCV. Hence, the gap in the Orimulsion emission factor partly comes from the difference between the GCV and the NCV emissions factors. Also, since some GCV emissions factors are only applicable to Japan, the gaps in the emissions factors of naphtha, petroleum coke, coking coal, and lignite indicate that the IPCC default GCV emissions factors are not universally applicable.
From 1990 to 2018, the average actual $\mathrm{CO}_{2}$ emissions of Orimulsion, natural gas liquids, naphtha, petroleum coke, coking coal, and lignite are 137,432.49 kt, 169,246.47 kt, -37,195.91 kt, -91,923.39 kt, 1,807.35 kt, 97,443.71 kt respectively, which account for $5.19 \%$ of total $\mathrm{CO}_{2}$ emission (EPA 2020). Because of the differences between IPCC and country-specific emissions factors for these six fuels, the total emissions reported by the United States are 1.00\% higher when using IPCC emissions factors than when using country-specific ones (EPA 2020).

Table 7: U.S. Emission Factors vs. IPCC Default

\begin{tabular}{|c|c|c|c|c|c|c|}
\hline \multirow{3}{*}{ FUEL TYPES } & & & Carbon Emission Factor & \multirow{3}{*}{ Note } & Carbon Emission Factor & Difference \\
\hline & & & $\mathrm{tC} / \mathrm{TJ}$ & & $\mathrm{tC} / \mathrm{TJ}$ & \multirow{2}{*}{$\%$} \\
\hline & & & $\mathrm{IPCC}^{*}$ & & Average & \\
\hline \multirow[t]{17}{*}{ Liquid fossil } & \multirow[t]{3}{*}{ Primary fuels } & Crude oil & 19.00 & & 19.20 & $-1 \%$ \\
\hline & & Orimulsion & 22.00 & & 19.20 & $15 \%$ \\
\hline & & Natural gas liquids & 18.26 & & 16.06 & $14 \%$ \\
\hline & \multirow[t]{14}{*}{ Secondary fuels } & Gasoline & 18.72 & 1) & 18.40 & $2 \%$ \\
\hline & & Jet kerosene & 18.60 & & 18.61 & $0 \%$ \\
\hline & & Other kerosene & 18.71 & 2) & 18.92 & $-1 \%$ \\
\hline & & Shale oil & 20.00 & & 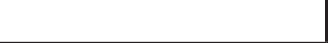 & \\
\hline & & Gas/diesel oil & 18.79 & 1) & 19.12 & $-2 \%$ \\
\hline & & Residual fuel oil & 20.17 & 1) & 19.41 & $4 \%$ \\
\hline & & Liquefied petroleum gases (LPG) & 16.38 & 1) & 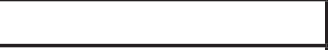 & \\
\hline & & Ethane & 16.80 & 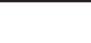 & & \\
\hline & & Naphtha & 18.63 & 1) & 17.58 & $6 \%$ \\
\hline & & Bitumen & 20.41 & 1) & 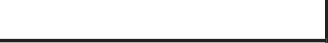 & . \\
\hline & & Lubricants & 19.89 & 1) & 19.15 & $4 \%$ \\
\hline & & Petroleum coke & 24.50 & 1) & 26.39 & $-7 \%$ \\
\hline & & Refinery feedstocks & 20.00 & 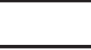 & 19.12 & $5 \%$ \\
\hline & & Other oil & 20.17 & 1) & 19.26 & $5 \%$ \\
\hline \multicolumn{2}{|c|}{ Other liquid fossil } & Special Naphtha & 18.63 & 1) & 18.71 & $0 \%$ \\
\hline \multirow[t]{9}{*}{ Solid fossil } & \multirow[t]{6}{*}{ Primary fuels } & Anthracite(3) & 25.92 & 1) & 26.80 & $-3 \%$ \\
\hline & & Coking coal & 24.42 & 1) & 29.38 & $-17 \%$ \\
\hline & & Other bituminous coal & 24.74 & 1) & 24.09 & $3 \%$ \\
\hline & & Sub-bituminous coal & 26.20 & & 25.08 & $4 \%$ \\
\hline & & Lignite & 26.82 & 1) & 25.23 & $6 \%$ \\
\hline & & Oil shale and tar sand & 29.10 & & & \\
\hline & \multirow[t]{3}{*}{ Secondary fuels } & BKB and patent fuel & 25.80 & & & \\
\hline & & Coke oven/gas coke & 30.22 & 1) & & \\
\hline & & Coal tar & & 3) & & \\
\hline \multicolumn{2}{|l|}{ Gaseous fossil } & Natural gas (dry) & 13.95 & 1) & 13.70 & $2 \%$ \\
\hline \multicolumn{2}{|l|}{ Biomass fossil } & Solid biomass & 29.9 & & & \\
\hline
\end{tabular}

Source: Prepared by the authors based on Inventory of U.S. Greenhouse Gas Emissions and Sinks 1990-2018 (EPA 2020) 


\subsection{Australia}

Table 8 presents a comparison between Australia's country-specific emission factors for each fuel type and IPCC default emission factors. Most fuel emission factors used in Australia are the same as IPCC default factors. Australia could improve the accuracy of its NIRs by including higher tier methods, especially in areas of particularly high emissions.
Also, the IPCC default emissions factor for coking coal is the same as the emissions factor for other bituminous coal, while empirical data in Australia and the United States indicate that the coking coal emissions factor is greater than the emissions factor for other bituminous coal (DISER 2020).

Table 8: Australia Emission Factors vs. IPCC Default

\begin{tabular}{|c|c|c|c|c|c|c|}
\hline & & & Carbon Emission Factor & & Carbon Emission Factor & Difference \\
\hline FUEL TYP & & & $\mathrm{tC} / \mathrm{TJ}$ & Note & t C/TJ & / \\
\hline & & & $\mathrm{IPCC}^{*}$ & & Average & \\
\hline Liquid fossil & Primary fuels & Crude oil & 20.00 & & 20.00 & $0 \%$ \\
\hline & & Natural gas liquids & 17.20 & & 17.20 & $0 \%$ \\
\hline & Secondary & Gasoline & 18.90 & 1) & 18.50 & $2 \%$ \\
\hline & & Jet kerosene & 19.55 & & 19.50 & $0 \%$ \\
\hline & & Other kerosene & 19.45 & 2) & 19.60 & $-1 \%$ \\
\hline & & Gas/diesel oil & 20.20 & 1) & 19.72 & $2 \%$ \\
\hline & & Residual fuel oil & 21.10 & 1) & 21.10 & $0 \%$ \\
\hline & & Liquefied petroleum gases (LPG) & 17.20 & 1) & 17.20 & $0 \%$ \\
\hline & & Naphtha & 20.00 & 1) & 20.00 & $0 \%$ \\
\hline & & Bitumen & 22.00 & 1) & 22.00 & $0 \%$ \\
\hline & & Lubricants & 20.00 & 1) & 20.00 & $0 \%$ \\
\hline & & Petroleum coke & 27.50 & 1) & 27.50 & $0 \%$ \\
\hline & & Refinery feedstocks & 20.00 & 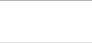 & 20.00 & $0 \%$ \\
\hline & & Other oil & 21.10 & 1) & 20.00 & $6 \%$ \\
\hline Solid fossil & Primary fuels & Anthracite & 26.80 & 1) & 26.80 & $0 \%$ \\
\hline & & Coking coal & 25.80 & 1) & 27.86 & $-7 \%$ \\
\hline & & Other bituminous coal & 25.80 & 1) & 25.86 & $0 \%$ \\
\hline & & Sub-bituminous coal & 26.20 & & 26.20 & $0 \%$ \\
\hline & & Lignite & 27.60 & 1) & 27.52 & $0 \%$ \\
\hline & Secondary & BKB and patent fuel & 25.80 & & 25.80 & $0 \%$ \\
\hline & & Coke oven/gas coke & 29.50 & 1) & 29.54 & $0 \%$ \\
\hline & & Coal tar & & 3) & 22.01 & \\
\hline Gaseous fossi & & Natural gas (dry) & 15.30 & 1) & 15.11 & $1 \%$ \\
\hline Waste (non-bi & ass fraction) & & & 3) & 26.37 & \\
\hline Peat $(5,6)$ & & & & & 28.90 & \\
\hline Biomass total & & Solid biomass & 29.90 & & 29.90 & $0 \%$ \\
\hline & & Liquid biomass & & 3) & 19.43 & \\
\hline & & Gas biomass & & 3) & 29.90 & \\
\hline & & Other non-fossil fuels (biogenic waste) & & 3) & 16.29 & \\
\hline $\begin{array}{l}\text { "Country-spe } \\
\text { 1) IPCC GCV/N } \\
\text { 2) IPCC defaul } \\
\text { 3) IPCC no det }\end{array}$ & $\begin{array}{l}\text { EF. If there's cou } \\
\text { Fjust for Japan } \\
\text { is not applicable } \\
\text { carbon emissio }\end{array}$ & $\begin{array}{l}\text { y-specific EF in IPCC database other that } \\
\text { actor for this fuel }\end{array}$ & ault, NCV and GCV value, will adopt & & pecific one & \\
\hline
\end{tabular}




\subsection{Germany}

Table 9 presents a comparison between Germany countryspecific emission factors for each fuel type and IPCC default emission factors. The variation in lignite results from the nature of lignite. As documented in the Germany NIR, the variances in Sulphur content are larger in lignite than in hard coal. Since the sulphur content has a noticeable effect on NCV and, thus, on the relationship between carbon content and NCV, lignite must be evaluated on a mining-district basis (Federal Republic of Germany 2020).
From 1990 to 2018, the average actual CO emissions of lignite and solid biomass are 196,890.04 kt, 51,563.93 kt respectively, which account for $23.84 \%, 6.24 \%$ of total $\mathrm{CO}_{2}$ emission respectively (Federal Republic of Germany 2020). Because of the differences between IPCC and countryspecific emissions factors for lignite and biomass, the total emissions reported by Germany are $2.11 \%$ higher and 0.95\% lower when using IPCC emissions factors than when using country-specific ones respectively (Federal Republic of Germany 2020).

Table 9: Germany Emission Factors vs. IPCC Default

\begin{tabular}{|c|c|c|c|c|c|c|}
\hline \multirow{2}{*}{\multicolumn{3}{|c|}{ FUEL TYPES }} & \multirow{3}{*}{$\begin{array}{c}\text { Carbon Emission Factor } \\
\text { tC/TJ } \\
\text { IPCC }^{\star}\end{array}$} & \multirow{4}{*}{ Note } & \multirow{3}{*}{$\begin{array}{c}\text { Carbon Emission Factor } \\
\text { tC/TJ } \\
\text { Average }\end{array}$} & \multirow{4}{*}{$\begin{array}{c}\text { Difference } \\
\% \\
0 \%\end{array}$} \\
\hline & & & & & & \\
\hline & & & & & & \\
\hline \multirow{11}{*}{ Liquid fossil } & Primary fuels & Crude oil & 20.00 & & 20.00 & \\
\hline & \multirow[t]{10}{*}{ Secondary fuels } & Gasoline & 18.90 & 1) & 19.99 & $-5 \%$ \\
\hline & & Jet kerosene & 19.55 & & 19.98 & $-2 \%$ \\
\hline & & Gas/diesel oil & 20.20 & 1) & 20.19 & $0 \%$ \\
\hline & & Residual fuel oil & 21.10 & 1) & 21.80 & $-3 \%$ \\
\hline & & Liquefied petroleum gases (LPG) & 17.20 & 1) & 17.82 & $-3 \%$ \\
\hline & & Naphtha & 20.00 & 1) & 19.99 & $0 \%$ \\
\hline & & Bitumen & 22.00 & 1) & 22.00 & $0 \%$ \\
\hline & & Lubricants & 20.00 & 1) & 19.99 & $0 \%$ \\
\hline & & Petroleum coke & 27.50 & 1) & 26.07 & $5 \%$ \\
\hline & & Other oil & 21.10 & 1) & 16.88 & $25 \%$ \\
\hline \multirow[t]{5}{*}{ Solid fossil } & \multirow[t]{2}{*}{ Primary fuels } & Other bituminous coal & 25.80 & 1) & 26.14 & $-1 \%$ \\
\hline & & Lignite & 27.60 & 1) & 30.28 & $-9 \%$ \\
\hline & \multirow[t]{3}{*}{ Secondary fuels } & BKB and patent fuel & 25.80 & . & 26.74 & $-4 \%$ \\
\hline & & Coke oven/gas coke & 29.50 & 1) & 29.45 & $0 \%$ \\
\hline & & Coal tar & & 3) & 86.46 & \\
\hline \multicolumn{2}{|c|}{ Gaseous fossil } & Natural gas (dry) & 15.30 & 1) & 15.24 & $0 \%$ \\
\hline \multicolumn{3}{|c|}{ Waste (non-biomass fraction) } & & 3) & 22.99 & \\
\hline \multicolumn{3}{|l|}{ Peat } & 28.90 & & 27.76 & $4 \%$ \\
\hline \multicolumn{2}{|l|}{ Biomass Total } & Solid biomass & 29.90 & & 25.95 & $15 \%$ \\
\hline
\end{tabular}

Source: Prepared by the authors based on National Inventory Report for the German Greenhouse Gas Inventory 1990 - 2018 (Federal Republic of Germany 2020) 


\section{Different Results Depending on the Method Applied: Case Study of Ger- many's Iron and Steel Industry}

\author{
4.1 Country-Specific Method vs. \\ Tier 2 Method vs. Tier 1 Method
}

The production of iron and steel is the second-largest $\mathrm{CO}_{2}$ emissions source in Germany's manufacturing sector. Moreover, Germany uses a mixture of Tier 2 (for fuel combustion) and country-specific methods (for metal production) to report emissions. These characteristics make Germany's iron and steel industry an ideal candidate for an examination of the impact of applying different methods.

In this section we calculate $\mathrm{CO}_{2}$ emissions through three methods: country specific, Tier 1 , and Tier 2 . $\mathrm{CO}_{2}$ emissions under the country-specific method are those reported in Germany's NIR (Juhrich 2017). Emissions under Tier 1 and Tier 2 are calculated based on the IPCC Guidelines. We obtained the activity data for Germany's iron and steel industry from Germany's Federal Statistical Office (Statistic of the Iron \& Steel Manufacturing Industry - Series 4 / Series 8.1 - Table 5.1 Consumption of solid and liquid fuel and Table 5.3 Production, receipts, consumption and deliveries of gas), Germany-specific emissions factors for fuels from Germany's NIR (Federal Republic of Germany 2020), and IPCC default factors for fuels from the IPCC database (IPCC 2008). Emissions under the Tier 2 method are calculated by multiplying the activity data by the Germany-specific emissions factor, while Tier 1 emissions are calculated by multiplying the activity data by the IPCC default emissions factor. The objective here is not to provide a complete estimation of $\mathrm{CO}_{2}$ emissions from the iron and steel industry, which might also entail estimating emissions from different industrial processes on a siteby-site basis. The goal, rather, is to compare results of the Tier 1 and Tier 2 methods by applying different emission factors (IPCC ones under Tier 1, and country-specific ones under Tier 2) to the same activity data.

Figure 1 represents Germany's iron and steel industry $\mathrm{CO}_{2}$ emissions calculated by Tier 1, Tier 2 and country-specific methods from 2005 to 2009. First, Tier 2 emissions are roughly 5\% greater than Tier 1 emissions because of the difference in the values of the emission factors. Germanyspecific fuel emissions factors are determined by Germany's fuel production level and import streams. For instance, the country's own production levels and imported streams of German natural gas have changed significantly since 1990, which results in the change in $\mathrm{CO}_{2} \mathrm{EF}$.

The countries of origin of German natural gas in 1990 and 2014 are shown in Figure 2. The values of German natural gas emissions factors range from $55.7 \mathrm{tCO}_{2} / \mathrm{TJ}$ to $55.9 \mathrm{tCO}_{2} /$ $\mathrm{TJ}$, which are lower than the IPCC default $\mathrm{CO}_{2}$ emissions factor of $56.1 \mathrm{t} \mathrm{CO}_{2} / \mathrm{TJ}$ (Juhrich 2017).
Figure 1: Germany Iron \& Steel CO2 Emissions

Source: Prepared by the authors based on Emission Factors for Fossil Fuels in Germany (Juhrich 2017)

\section{Germany Iron \& Steel CO2 Emission (country vs IPCC standard)}

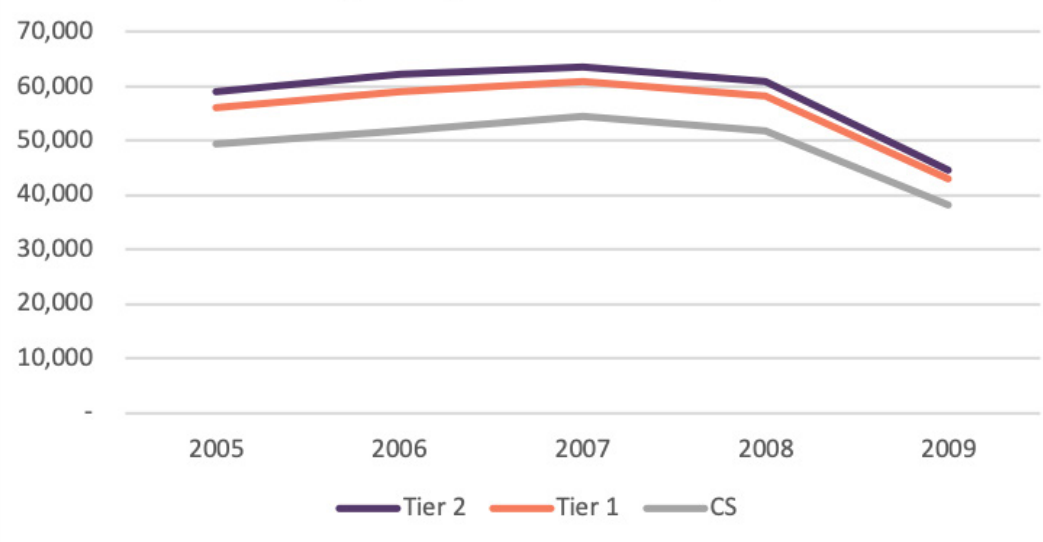


Second, Tier 2 emissions are roughly 15\% greater than country-specific emissions. One reason behind this discrepancy is the difference in categorization. The categorization of the IPCC Tier 2 method is based on fuel type only, while in Germany's NIR, the iron and steel manufacturing industry sub-category is categorized by fuel types (liquid fuels, solid fuels, gaseous fuels, other fossil fuels, peat, biomass), and the metal production sub-category is categorized by steel type (steel, pig iron, direct reduced iron, sinter, pellet and others). Another reason is the difference in country-specific emission factors. Hard coal for iron and steel industry $\mathrm{CO}_{2}$ emission factor in Germany ranges from 2.86 to $2.99 \mathrm{t} \mathrm{CO}_{2} / \mathrm{t}$ while other hard-coal products $\mathrm{CO}_{2}$ emission factor ranges from 3.27 to 3.33 t CO $/$ /t in Germany (Federal Republic of Germany 2020).

Figure 2: Countries of Origins of Natural Gas Used in Germany, 1990 \& 2014
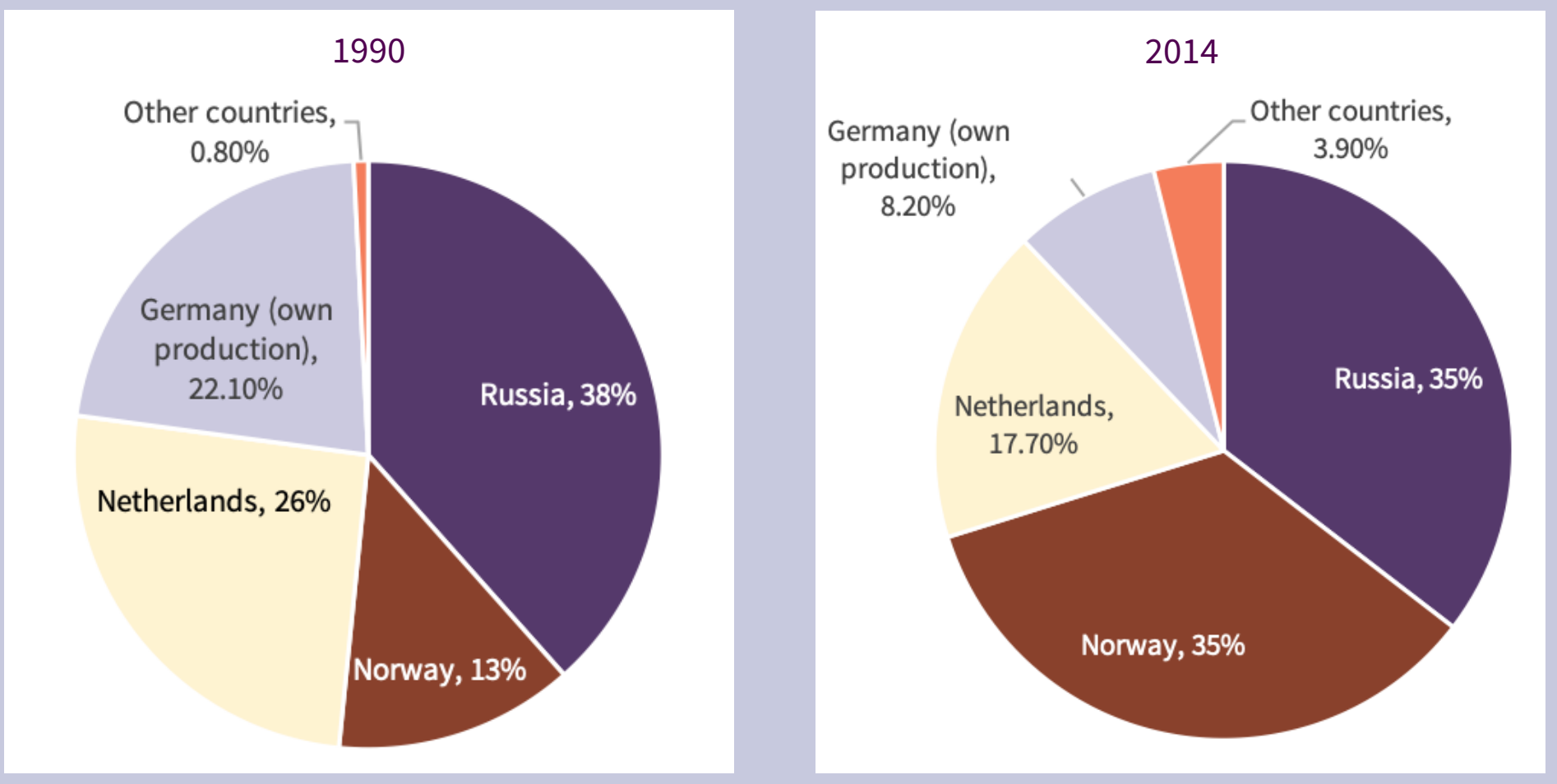


\subsection{Tier 3 Method vs. Tier 2 Method}

In 1A3b (Road Transportation), Germany uses the Tier 2 method for $\mathrm{CO}_{2}$ emissions and the Tier 3 method for $\mathrm{CH}_{4}$ emissions. See in Table 10 the example of Germany's 2018 Gasoline emissions factors in Road Transportation.

Since the $\mathrm{CO}_{2}$ emissionsfactorsfollow the Tier 2 method, the emissionsfactoris thesame among different transportation types. However, emissions factors of $\mathrm{CH}_{4}$ are different among different transportation types. The main difference between Tier 2 and Tier 3 method is the granularity of emission factors.

\section{Applying the NIR Reporting Frame- work in a Developing Country: Case Study of China}

This section will assess the reporting standards applicable to BURs, examining the disparity between non-Annex I Parties' BUR reporting practices and Annex I Parties' NIR reporting practices in line with the IPCC Guidelines. China, which has submitted two BURs but no NIRs, will be used as a case study to illustrate the differences (People's Republic of China (PRC) 2018).

Table 10: Germany Emission Factors for Road Transportation

\begin{tabular}{|c|c|c|c|c|c|c|c|c|}
\hline \multirow{3}{*}{$\begin{array}{l}\text { GREENHOUSE GAS } \\
\text { SOURCE AND SINK } \\
\text { CATEGORIES }\end{array}$} & \multicolumn{2}{|c|}{ AGGREGATE ACTIVITY DATA } & \multicolumn{3}{|c|}{ IMPLIED EMISSION FACTORS } & \multicolumn{3}{|c|}{ EMISSIONS } \\
\hline & \multicolumn{2}{|c|}{ Consumption } & $\mathrm{CO}_{2}$ & $\mathrm{CH}_{4}$ & $\mathrm{~N}_{2} \mathrm{O}$ & $\mathrm{CO}_{2}$ & $\mathrm{CH}_{4}$ & $\mathrm{~N}_{2} \mathrm{O}$ \\
\hline & (TJ) & NCV/GCV & $(\mathrm{t} / \mathrm{TJ})$ & $(\mathrm{kg} /$ & & & (kt) & \\
\hline b. Road transportation & 2201911.67 & NCV & & & & 155812.70 & 8.73 & 5.62 \\
\hline Gasoline & 692694.00 & NCV & 75.29 & 8.59 & 0.49 & 52149.52 & 5.95 & 0.34 \\
\hline i. Cars & 1362386.10 & NCV & & & & 96896.15 & 5.91 & 2.62 \\
\hline Gasoline & 668336.72 & NCV & 75.29 & 5.25 & 0.47 & 50315.78 & 3.51 & 0.31 \\
\hline ii. Light duty trucks & 160077.52 & NCV & & & & 11223.35 & 0.24 & 0.37 \\
\hline Gasoline & 6441.91 & NCV & 75.29 & 12.45 & 1.30 & 484.98 & 0.08 & 0.01 \\
\hline $\begin{array}{l}\text { iii. Heavy duty trucks } \\
\text { and buses }\end{array}$ & 660651.97 & NCV & & & & 46335.09 & 0.11 & 2.62 \\
\hline Gasoline & NO & NCV & NA & NA & NA & NA & NA & NA \\
\hline iv. Motorcycles & 18720.91 & NCV & & & & 1352.61 & 2.47 & 0.02 \\
\hline Gasoline & 17915.37 & NCV & 75.29 & 132.16 & 1.12 & 1348.76 & 2.37 & 0.02 \\
\hline
\end{tabular}


Table 11: China Methodology Choice

\begin{tabular}{|c|c|c|c|c|}
\hline IPCC Category Code & Source/ Sink Categories & $\mathrm{CO}_{2}$ & $\mathrm{CH}_{4}$ & $\mathrm{~N}_{2} \mathrm{O}$ \\
\hline $1 \mathrm{~A} 1$ & Energy industry & $\mathrm{T} 2$ & $\mathrm{~T} 1, \mathrm{~T} 2$ & $\mathrm{~T} 1, \mathrm{~T} 2$ \\
\hline $1 \mathrm{~A} 2$ & Manufacturing industries and construction & T2 & $\mathrm{T} 1$ & $\mathrm{~T} 1$ \\
\hline $1 \mathrm{A3}$ & Transportation & T2 & $\mathrm{T} 1, \mathrm{~T} 3$ & $\mathrm{~T} 1, \mathrm{~T} 3$ \\
\hline $1 \mathrm{~A} 4,1 \mathrm{~A} 5 \mathrm{a}$ & Other sectors & T2 & $\mathrm{T} 1$ & $\mathrm{~T} 1$ \\
\hline $1 \mathrm{~A} 5 \mathrm{~b}$ & Other & $\mathrm{T} 2$ & $\mathrm{~T} 1, \mathrm{~T} 2$ & $\mathrm{~T} 1, \mathrm{~T} 2$ \\
\hline 1B1 & Fugitive emissions from solid fuels & & $\mathrm{T} 1, \mathrm{~T} 2$ & \\
\hline 1B2 & Fugitive emissions from oil and natural gas & & $\mathrm{T} 1, \mathrm{~T} 3$ & \\
\hline $2 \mathrm{~A}$ & Mineral products & $\mathrm{T} 1, \mathrm{~T} 2$ & & \\
\hline $2 \mathrm{~B}$ & Chemical industry & $\mathrm{T} 1, \mathrm{~T} 2$ & $\mathrm{NE}$ & T3 \\
\hline $2 \mathrm{C}$ & Metal production & $\mathrm{T} 1, \mathrm{~T} 2$ & $\mathrm{~T} 1$ & $\mathrm{NE}$ \\
\hline $3 \mathrm{~A}$ & Enteric fermentation & & $\mathrm{T} 1, \mathrm{~T} 2$ & \\
\hline $3 B$ & Manure management & & $\mathrm{T} 1, \mathrm{~T} 2$ & T2 \\
\hline $3 C$ & Rice cultivation & & T3 & \\
\hline 3D & Agricultural soils & & $\mathrm{NE}$ & $\mathrm{T} 1, \mathrm{~T} 2$ \\
\hline $3 F$ & Field burning of agricultural residues & & $\mathrm{T} 1$ & $\mathrm{~T} 1$ \\
\hline $4 \mathrm{~A}$ & Forest land & $\mathrm{T} 2$ & & \\
\hline $4 \mathrm{~B}$ & Cropland & T3 & IE & IE \\
\hline $4 C$ & Grassland & $\mathrm{T} 2$ & IE & IE \\
\hline $4 \mathrm{D}$ & Wetlands & $\mathrm{T} 2$ & T2 & $\mathrm{NE}$ \\
\hline $4 \mathrm{E}$ & Settlements & $\mathrm{T} 2$ & & \\
\hline $4 \mathrm{~F}$ & Other land & $\mathrm{T} 1$ & & \\
\hline $4 G$ & Harvested wood products & $\mathrm{T} 2$ & & \\
\hline $5 \mathrm{~A}$ & Solid waste & $\mathrm{T} 1, \mathrm{~T} 2$ & $\mathrm{~T} 1, \mathrm{~T} 2$ & $\mathrm{~T} 1$ \\
\hline $5 \mathrm{D}$ & Wastewater treatment & & $\mathrm{T} 1, \mathrm{~T} 2$ & $\mathrm{~T} 1, \mathrm{~T} 2$ \\
\hline
\end{tabular}

Source: Prepared by the authors based on The People's Republic of China

Second Biennial Update Report on Climate Change (PRC 2018)

\subsection{Reporting Scope}

Both Chinese BURs only include a National Gas Inventory (NGI) for the latest period. Having submitted two versions of National Communication on Climate Change Report and two versions of BURs, China only reported its National Gas Inventory in 1994, 2005, 2012, and 2014. The lack of continuity in GHG reporting indicates the value of recommending annual NIRs.

\subsection{Key Category Analysis}

China carried out a key category analysis for its NGI of 2010 and identified 40 key categories (PRC 2018). Emissions from key categories were calculated with higher-tier methods and country-specific emission factors, which complied with IPCC requirements. However, China adopted the same result for its 2014 NGI report as in 2010, without carrying out a new key category analysis.

\subsection{Methodology Choice}

China has not documented the reporting methods of HFCs, $\mathrm{SF}_{6}$, and PFC. For $\mathrm{CO}_{2}, \mathrm{CH}_{4}$, and $\mathrm{N}_{2} \mathrm{O}$, the methodology used in China's BUR is listed in Table 11.

Overall, the granularity of the category disaggregation is lower than Annex I Parties NIR reports. Also, the methodology of China's BUR fully followed Tier methods defined in the IPCC Guidelines. The granularity of Tier methods in each category aligns with the practice of Annex I Parties in their NIRs. 


\subsection{Quality Assurance and Quality Control}

In the second BUR, China adopted several improvements to reduce uncertainties and improve the quality of inventory, which made its reporting standard more similar to the NIR reporting framework provided by the IPCC Guidelines (PRC 2018).

Regarding the activity data, China's National Bureau of Statistics (NBS) established a statistical reporting system by sector that increased the types of energy statistics reported. This new system would be useful in the adoption of the sectoral approach, as required by the IPCC Guidelines (PRC 2018).

Regarding the calorific value method, China conducted further investigation on the NCV of coals consumed in key sectors by type and purpose; the results have not been made public.

In terms of emissions factors, the NBS initially established a relevant parameter statistical survey system revealing sector-specific emission factors. The inventory team and other relevant departments researched the rate of carbon storage in the coal chemical industry, on-site measurement of nitrogen excretion by primary livestock and poultry, and direct emission factors of $\mathrm{N}_{2} \mathrm{O}$ from agricultural soils to obtain country-specific emission factors and related parameters.

\subsection{Summary}

Given the granularity of China's BUR, it would be feasible for China to apply the existing data reporting system in NIR reporting. More efforts will be needed to calculate the GHG in previous years and further break down categories.

\section{Findings and Recommendations}

The empirical research on NIRs of Australia, Germany, Japan, and the United States reveals a difference between the IPCC Guidelines and the practice of Annex I countries. Even if all four countries follow the IPCC decision tree to determine methodologies used for each category, the methodologies used by each country are country-specific. Countries normally compare emissions estimated by the bottom-up sectoral approach with the top-down reference approach, but results generated by two approaches are significantly different (IPCC 2006). Categories and gases reported by each country are different from the suggestions in IPCC Guidelines. The granularity levels and tier methods for same categories are different in different countries' NIRs. There often are significant differences between country-specific emission factors and IPCC default emission factors, which were calculated based on 1990s data from OECD countries. The Germany Iron and Steel Industry case study reveals that emissions calculated by different tier methods and the country-specific method are different for the same categories. In turn, Non-Annex I countries like China have not fully applied IPCC Guidelines when reporting emissions, given the lack of continuous emission reporting and completed preliminary analysis.

The empirical research reveals that the good-faith application of the IPCC Guidelines can lead to widely diverging results, andthus makesthecaseforharmonization of GHG accounting frameworks. The comparison among the four countries also reveals the potentials for countries to adopt each other's advanced emission reporting standards and converge to a consolidated framework.

To improve the consistency and comparability of emissions inventories by various countries, we recommend that the IPCC adopt, based on a mandate from the Conference of the Parties to the UNFCCC, a consolidated framework that could be used for emissions reports of both Annex I and Non-Annex I countries. We also recommend that the IPCC and the UNFCCC offer a forum for governments (and their national carbon accounting bodies) to collaborate in harmonizing emissions accounting by sharing methods, data, and experience. The IPCC may also provide best practice for methodologies used in each category, based on country practice. The IPCC should continue to update default emission factors periodically, as it did in the 2019 Refinement (IPCC 2019), and for as many categories as feasible, so that emission factors are representative of the most recently calculated carbon intensity of fuels, as well as applicable to both Annex I and Non-Annex I countries. 


\section{Comparison Between the IPCC Reporting Framework and Country Practice}

\section{Appendix 1: CRF Sector Code}

Source: Prepared by the authors based on 2006 IPCC Guidelines for National Greenhouse Gas Inventories (IPCC 2008)

\begin{tabular}{|c|c|}
\hline 1 ENERGY & $2 E 1$ Integrated Circuit or Semiconductor \\
\hline 1A Fuel Combustion Activities & 2E2 TFT Flat Panel Display \\
\hline 1 A1 Energy Industries & 2 2E3 Photovoltaics \\
\hline 1A2 Manufacturing Industries and Construction & 2 2E4 Heat Transfer Fluid \\
\hline 1A3 Transport & $2 E 5$ Other (please specify) \\
\hline $1 \mathrm{~A} 4$ Other Sectors & 2F Product Uses as Substitutes for Ozone Depleting Substances \\
\hline 1A5 Non-Specified & 2F1 Refrigeration and Air Conditioning \\
\hline 1B Fugitive Emissions from Fuels & 2F2 Foam Blowing Agents \\
\hline 1B1 Solid Fuels & $2 F 3$ Fire Protection \\
\hline 1B2 Oil and Natural Gas & 2F4 Aerosols \\
\hline 1B3 Other Emissions from Energy Production & $2 F 5$ Solvents \\
\hline 1C Carbon Dioxide Transport and Storage & $2 F 6$ Other Applications \\
\hline 1C1 Transport of $\mathrm{CO} 2$ & $2 \mathrm{G}$ Other Product Manufacture and Use \\
\hline 1 C2 Injection and Storage & 2 G1 Electrical Equipment \\
\hline 2 INDUSTRIAL PROCESSES AND PRODUCT USE & 2 G2 SF6 and PFCs from Other Product Uses \\
\hline $2 A$ Mineral Industry & $2 \mathrm{G} 3 \mathrm{~N} 2 \mathrm{O}$ from Product Uses \\
\hline 2A1 Cement Production & 264 Other (please specify) \\
\hline 2A2 Lime Production & $2 \mathrm{H}$ Other (please specify) \\
\hline 2A3 Glass Production & 2H1 Pulp and Paper Industry \\
\hline $2 \mathrm{~A} 4$ Other Process Uses of Carbonates & $2 \mathrm{H} 2$ Food and Beverages Industry \\
\hline 2 A5 Other (please specify) & 2H3 Other (please specify) \\
\hline 2B Chemical Industry & 3AGRICULTURE \\
\hline 2B1 Ammonia Production & 3A Enteric Fermentation \\
\hline 2B2 Nitric Acid Production & 3B Manure Management \\
\hline 2B3 Adipic Acid Production & 3C Rice Cultivation \\
\hline 2B4 Caprolactam, Glyoxal and Glyoxylic Acid Production Production & 3D Agricultural Soils \\
\hline 2B5 Carbide Production & 3E Prescribed Burning of Savannas \\
\hline $2 B 6$ Titanium Dioxide Production & 3F Field Burning of Agricultural Residues \\
\hline 2B7 Soda Ash Production & 3G Liming \\
\hline 2B8 Petrochemical and Carbon Black Production & 3H Urea application \\
\hline 2B9 Fluorochemical Production & 31 Other carbon-containing fertilizers \\
\hline 2B10 Other (please specify) & 3J Other \\
\hline 2C Metal Industry & 4 LAND USE, LAND-USE CHANGE AND FORESTRY \\
\hline $2 \mathrm{Cl}$ Iron and Steel Production & 4AForest land \\
\hline 2 C2 Ferroalloys Production & 4B Cropland \\
\hline 2C3 Aluminium Production & 4C Grassland \\
\hline $2 C 4$ Magnesium Production & 4D Wetlands \\
\hline 2 C5 Lead Production & 4E Settlements \\
\hline 2C6 Zinc Production & 4F Other land \\
\hline $2 \mathrm{C7}$ Other (please specify) & 4G Harvested Wood Products \\
\hline 2D Non-Energy Products from Fuels and Solvent Use & 5 WASTE \\
\hline 2D1 Lubricant Use & 5A Solid Waste Disposal \\
\hline 2D2 Paraffin Wax Use & 5B Biological Treatment of Solid Waste \\
\hline 2D3 Solvent Use & 5C Incineration and Open Burning of Waste \\
\hline $2 \mathrm{D} 4$ Other (please specify) & 5D Wastewater Treatment and Discharge \\
\hline 2E Electronics Industry & 5E Other \\
\hline
\end{tabular}




\section{Appendix 2: IPCC's Suggested Greenhouse Gases to Be Assessed}

Source: Prepared by the authors based on 2006 IPCC Guidelines for National Greenhouse Gas Inventories (IPCC 2008)

\begin{tabular}{|c|c|c|c|c|c|c|}
\hline & $\mathrm{CO}_{2}$ & $\mathrm{CH}_{4}$ & $\mathrm{~N}_{2} \mathrm{O}$ & HFCs & $\mathrm{SF}_{6}$ & PFC \\
\hline $1 \mathrm{Ala}$ & $x$ & $x$ & $x$ & & & \\
\hline $1 \mathrm{Alb}$ & $x$ & $x$ & $x$ & & & \\
\hline 1AlC & $x$ & $x$ & $x$ & & & \\
\hline $1 \mathrm{~A} 2 \mathrm{a}$ & $x$ & $x$ & $x$ & & & \\
\hline $1 \mathrm{~A} 2 \mathrm{~b}$ & $x$ & $x$ & $x$ & & & \\
\hline $1 \mathrm{~A} 2 \mathrm{C}$ & $x$ & $x$ & $x$ & & & \\
\hline $1 \mathrm{~A} 2 \mathrm{~d}$ & $x$ & $x$ & $x$ & & & \\
\hline 1A2e & $x$ & $x$ & $x$ & & & \\
\hline $1 \mathrm{~A} 2 \mathrm{f}$ & $x$ & $x$ & $x$ & & & \\
\hline $1 \mathrm{~A} 2 \mathrm{~g}$ & $x$ & $x$ & $x$ & & & \\
\hline 1A3a & $x$ & $x$ & $x$ & & & \\
\hline $1 \mathrm{~A} 3 \mathrm{~b}$ & $x$ & $x$ & $x$ & & & \\
\hline $1 \mathrm{~A} 3 \mathrm{C}$ & $x$ & $x$ & $x$ & & & \\
\hline $1 \mathrm{A3d}$ & $x$ & $x$ & $x$ & & & \\
\hline $1 \mathrm{A3e}$ & $x$ & $x$ & $x$ & & & \\
\hline $1 \mathrm{~A} 4 \mathrm{a}$ & $x$ & $x$ & $x$ & & & \\
\hline $1 \mathrm{~A} 4 \mathrm{~b}$ & $x$ & $x$ & $x$ & & & \\
\hline $1 \mathrm{~A} 4 \mathrm{C}$ & $x$ & $x$ & $x$ & & & \\
\hline $1 \mathrm{~A} 5 \mathrm{a}$ & $x$ & $x$ & $x$ & & & \\
\hline $1 \mathrm{~A} 5 \mathrm{~b}$ & $x$ & $x$ & $x$ & & & \\
\hline 1B1ai & $x$ & $x$ & & & & \\
\hline 1B1aii & $x$ & $x$ & & & & \\
\hline Post Mining & $x$ & $x$ & & & & \\
\hline 1B1c(Decommissioned mines) & $x$ & $x$ & & & & \\
\hline 1B1c(Flaring) & $x$ & $x$ & & & & \\
\hline 1B2ai & $x$ & $x$ & & & & \\
\hline 1B2aii & $x$ & $x$ & & & & \\
\hline 1B2aiii & $x$ & $x$ & & & & \\
\hline 1B2aiv(refining) & $x$ & $x$ & & & & \\
\hline 1B2aiv(storage) & $x$ & $x$ & & & & \\
\hline 1B2av & $x$ & $x$ & & & & \\
\hline 1B2avi & $x$ & $x$ & & & & \\
\hline $1 \mathrm{~B} 2 \mathrm{bi}$ & $x$ & $x$ & & & & \\
\hline 1B2bii & $x$ & $x$ & & & & \\
\hline 1B2biii & $x$ & $x$ & & & & \\
\hline 1B2biv(transportation) & $x$ & $x$ & & & & \\
\hline 1B2biv(storage) & $x$ & $x$ & & & & \\
\hline $1 \mathrm{~B} 2 \mathrm{bv}$ & $x$ & $x$ & & & & \\
\hline 1B2bvi & $x$ & $x$ & & & & \\
\hline $2 \mathrm{~A} 1$ & $x$ & & & & & \\
\hline $2 \mathrm{~A} 2$ & $x$ & & & & & \\
\hline
\end{tabular}




\begin{tabular}{|c|c|c|c|c|c|c|}
\hline & $\mathrm{CO}_{2}$ & $\mathrm{CH}_{2}$ & $\mathrm{~N}_{2} \mathrm{O}$ & HFCs & $\mathrm{SF}_{6}$ & PFC \\
\hline $2 \mathrm{~A} 3$ & x & & & & & \\
\hline $2 \mathrm{~A} 4 \mathrm{a}$ & $x$ & & & & & \\
\hline $2 \mathrm{~A} 4 \mathrm{~b}$ & $x$ & & & & & \\
\hline 2B1 & $x$ & & & & & \\
\hline $2 \mathrm{~B} 2$ & & & x & & & \\
\hline 2B3 & & & $x$ & & & \\
\hline $2 \mathrm{~B} 4$ & & & $x$ & & & \\
\hline $2 \mathrm{~B} 5$ & $x$ & $x$ & & & & \\
\hline $2 \mathrm{~B} 6$ & $x$ & & & & & \\
\hline $2 \mathrm{~B} 7$ & $x$ & & & & & \\
\hline $2 \mathrm{~B} 8$ & $x$ & $x$ & & & & \\
\hline 2B9 & & & & $x$ & $x$ & $x$ \\
\hline $2 \mathrm{Cl}$ & $x$ & $x$ & & & & \\
\hline $2 \mathrm{C} 2$ & $x$ & $x$ & & & & \\
\hline $2 \mathrm{C} 3$ & $x$ & & & & & $x$ \\
\hline $2 \mathrm{C} 4$ & $x$ & & & x & $x$ & $x$ \\
\hline $2 \mathrm{C5}$ & $x$ & & & & & \\
\hline $2 \mathrm{C} 6$ & $x$ & & & & & \\
\hline $2 \mathrm{D} 7$ & $x$ & & & & & \\
\hline 2D1 & $x$ & & & & 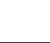 & \\
\hline $2 \mathrm{D} 2$ & $x$ & & & & & \\
\hline $2 \mathrm{D} 3$ & $x$ & & & & & \\
\hline $2 \mathrm{E}$ & & & & $x$ & $x$ & $x$ \\
\hline $2 \mathrm{~F}$ & & & & x & & $x$ \\
\hline $2 \mathrm{G}$ & 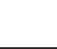 & & $x$ & & $x$ & $x$ \\
\hline $3 A 2,3$ & 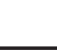 & $x$ & $x$ & & & \\
\hline $3 \mathrm{~A} 1$ & & $x$ & & & & \\
\hline $3 \mathrm{~B} 1,3$ & $x$ & & . & & & \\
\hline $3 \mathrm{~B} 2,4$ & $x$ & . & $x$ & & & \\
\hline 3B5 & $x$ & & & & & \\
\hline $3 C$ & $x$ & $x$ & $x$ & & & \\
\hline 3Dla,b,c,e,f,g & $x$ & . & & & & \\
\hline 3D1h & $x$ & & & & & \\
\hline $4 \mathrm{~A} 1$ & & $x$ & & & & \\
\hline $4 \mathrm{~A} 2$ & & $x$ & 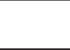 & & & \\
\hline 4B1 & & $x$ & $x$ & & & \\
\hline $4 \mathrm{~B} 2$ & 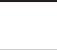 & $x$ & $x$ & & & \\
\hline $4 \mathrm{Cl}$ & $x$ & $x$ & $x$ & & & \\
\hline $4 C 2$ & $x$ & $x$ & $x$ & & & \\
\hline 4D1 & & $x$ & $x$ & & & \\
\hline 4D2 & & $x$ & x & & & \\
\hline $5 \mathrm{~A}$ & 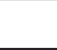 & & $x$ & & 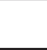 & \\
\hline 5B1 & $x$ & $x$ & $x$ & $x$ & x & $x$ \\
\hline $5 B 2$ & $x$ & $x$ & $x$ & $x$ & $x$ & $x$ \\
\hline
\end{tabular}




\section{Appendix 3: Germany's Methodology Choice}

Source: Prepared by the authors based on National Inventory Report for the German Greenhouse Gas Inventory 1990 - 2018 (Federal Republic of Germany 2020)

\begin{tabular}{|c|c|c|c|c|c|c|c|c|c|c|c|}
\hline \multicolumn{12}{|c|}{ Germany } \\
\hline & $\mathrm{CO}_{2}$ & $\mathrm{CH}_{4}$ & $\mathrm{~N}_{2} \mathrm{O}$ & $\mathrm{NO}_{x}$ & $\mathrm{CO}$ & NMVOC & $\mathrm{SO}_{2}$ & HFCS & $\mathrm{SF}_{6}$ & PFC & $\mathrm{NF}_{3}$ \\
\hline $1 \mathrm{Dla}$ & 3 & 3 & 3 & 3 & 3 & 3 & 1 & & & & \\
\hline $1 \mathrm{D} 1 \mathrm{~b}$ & 2 & 2 & 2 & 2 & 2 & 2 & 2 & & & & \\
\hline 1Ala & $\mathrm{CS}$ & 2 & 2 & CS & $\mathrm{CS}$ & CS & CS & & & & \\
\hline $1 \mathrm{Alb}$ & $\mathrm{CS}$ & 2 & 2 & CS & $\mathrm{CS}$ & CS & $\mathrm{CS}$ & & & & \\
\hline $1 \mathrm{AlC}$ & $\mathrm{CS}$ & 2 & 2 & $\mathrm{CS}$ & $\mathrm{CS}$ & $\mathrm{CS}$ & $\mathrm{CS}$ & & & & \\
\hline $1 \mathrm{~A} 2 \mathrm{a}$ & CS & CS & CS & CS & $\mathrm{CS}$ & CS & $\mathrm{CS}$ & & & & \\
\hline $1 \mathrm{~A} 2 \mathrm{~b}$ & $\mathrm{CS}$ & $\mathrm{CS}$ & $\mathrm{CS}$ & $\mathrm{CS}$ & $\mathrm{CS}$ & $\mathrm{CS}$ & CS & & & & \\
\hline $1 \mathrm{~A} 2 \mathrm{C}$ & IE & IE & $\mathrm{IE}$ & $\mathrm{IE}$ & $\mathrm{IE}$ & $\mathrm{IE}$ & $\mathrm{IE}$ & & & & \\
\hline $1 \mathrm{~A} 2 \mathrm{~d}$ & $\mathrm{CS}$ & $\mathrm{CS}$ & $\mathrm{CS}$ & $\mathrm{IE}$ & $\mathrm{IE}$ & $\mathrm{IE}$ & $\mathrm{IE}$ & & & & \\
\hline $1 \mathrm{~A} 2 \mathrm{e}$ & CS & CS & CS & $\mathrm{CS}$ & $\mathrm{CS}$ & CS & $\mathrm{CS}$ & & & & \\
\hline $1 \mathrm{~A} 2 \mathrm{f}$ & $\mathrm{CS}$ & $\mathrm{CS}$ & $\mathrm{CS}$ & $\mathrm{CS}$ & $\mathrm{CS}$ & $\mathrm{CS}$ & $\mathrm{CS}$ & & & & \\
\hline $1 \mathrm{~A} 2 \mathrm{~g}$ & $\mathrm{CS}$ & $\mathrm{CS}$ & $\mathrm{CS}$ & $\mathrm{CS}$ & $\mathrm{CS}$ & $\mathrm{CS}$ & $\mathrm{CS}$ & & & & \\
\hline $1 \mathrm{A3a}$ & 3 & 3 & 3 & 3 & 3 & 3 & 1 & & & & \\
\hline $1 \mathrm{~A} 3 \mathrm{~B}$ & 2 & 3 & 3 & 3 & 3 & 3 & 3 & & & & \\
\hline $1 \mathrm{A3C}$ & 2 & 2 & 2 & 2 & 2 & 2 & 2 & & & & \\
\hline $1 \mathrm{A3d}$ & 2 & 2 & 2 & 2 & 2 & 2 & 2 & & & & \\
\hline $1 \mathrm{A3e}$ & $\mathrm{CS}$ & 2 & 2 & 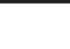 & & 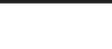 & 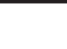 & & & & \\
\hline $1 \mathrm{~A} 4$ & $\mathrm{CS}$ & 2 & 2 & 2 & 2 & 2 & 2 & & & & \\
\hline $1 \mathrm{~A} 5 \mathrm{a}$ & CS & 3 & 3 & 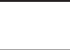 & . & 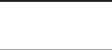 & 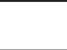 & & & & \\
\hline $1 \mathrm{~A} 5 \mathrm{~b}$ & $\mathrm{CS}$ & 3 & 3 & 3 & 3 & 3 & 3 & & & & \\
\hline underground mining - hard coal & $M$ & 3 & & 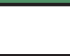 & & 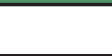 & 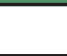 & & & & \\
\hline Open-pit mining - lignite & & 2 & & & & & 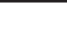 & & & & \\
\hline Solid fuel transformation & 2 & 2 & & & 2 & 2 & 2 & & & & \\
\hline 1B2ai & 1 & 1 & & & & 2 & & & & & \\
\hline 1B2aii & 2 & 2 & & & & 2 & & & & & \\
\hline 1B2aiii & & 2 & & & & 2 & 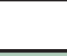 & & & & \\
\hline 1B2aiv & 2 & 2 & & 2 & 2 & 2 & 2 & & & & \\
\hline 1B2av & & & & & & 2 & & & & & \\
\hline 1B2bi & & IE & & & & IE & & & & & \\
\hline 1B2bii & 2 & 2 & & & & 2 & 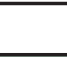 & & & & \\
\hline 1B2biii & 2 & 2 & & & 2 & 2 & 2 & & & & \\
\hline 1B2biv(transmission) & & 3 & & & & & & & & & \\
\hline 1B2biv(storage) & & 2 & & & & & & & & & \\
\hline $1 \mathrm{~B} 2 \mathrm{bv}$ & & 3 & & & & & & & & & \\
\hline 1B2bvi & & 2 & & & & & & & & & \\
\hline $1 B 2 C$ & 2 & 2 & 2 & & & 2 & & & & & \\
\hline $2 \mathrm{~A} 1$ & 2 & & & 1 & & & 1 & & & & \\
\hline $2 \mathrm{~A} 2$ & 2 & & & 1 & & & 1 & & & & \\
\hline
\end{tabular}

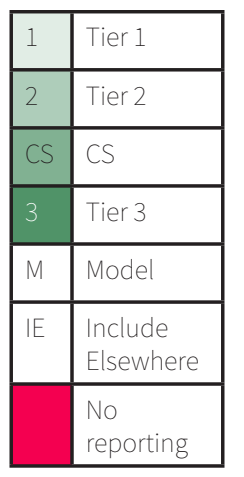




\begin{tabular}{|c|c|c|c|c|c|c|c|c|c|c|c|}
\hline \multicolumn{12}{|c|}{ Germany } \\
\hline & $\mathrm{CO}_{2}$ & $\mathrm{CH}_{4}$ & $\mathrm{~N}_{2} \mathrm{O}$ & $\mathrm{NO}_{\mathrm{x}}$ & $\mathrm{CO}$ & NMVOC & $\mathrm{SO}_{2}$ & HFCs & $\mathrm{SF}_{6}$ & PFC & $\mathrm{NF}_{3}$ \\
\hline $2 \mathrm{A3}$ & 2 & & & 2 & & 2 & 2 & & & & \\
\hline $2 A 4 a$ & 2 & & & 1 & & 1 & 1 & & & & \\
\hline $2 A 4 b$ & 1 & & & & & & & & & & \\
\hline $2 \mathrm{~B} 1$ & 3 & & & & & & & & & & \\
\hline $2 \mathrm{~B} 2$ & . & & 3 & & & & & & & & \\
\hline $2 \mathrm{~B} 3$ & 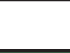 & & 3 & & & & & & & & \\
\hline $2 \mathrm{~B} 5$ & 3 & . & & & & & & & & & \\
\hline $2 B 7$ & 1 & 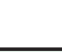 & & & & & & & & & \\
\hline $2 \mathrm{~B} 8$ & CS & 1 & & & 1 & 1 & 1 & . & 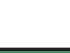 & 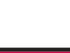 & \\
\hline $2 \mathrm{~B} 9$ & & & & & & & & 3 & 3 & 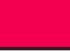 & \\
\hline $2 \mathrm{Cl}$ & 2 & 2 & CS & 2 & 2 & 2 & 2 & 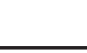 & 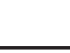 & 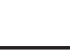 & \\
\hline $2 \mathrm{C} 2$ & CS & . & & & & & & & 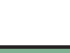 & 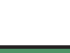 & \\
\hline $2 \mathrm{C} 3$ & 3 & 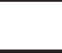 & & & & & & 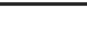 & CS & 3 & \\
\hline $2 \mathrm{C} 4$ & 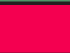 & & & & & & & 1 & 1 & . & \\
\hline $2 \mathrm{C5}$ & 1 & & & & & & & & & 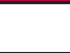 & \\
\hline $2 \mathrm{C6}$ & 1 & & & & & & & 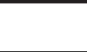 & 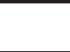 & & \\
\hline $2 \mathrm{D1}$ & 2 & & & & & 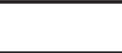 & & 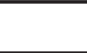 & 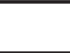 & & \\
\hline $2 \mathrm{D} 2$ & 1 & & 1 & & & 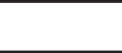 & & 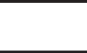 & 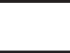 & & \\
\hline $2 \mathrm{D3}$ & 1 & & & 1 & & 2 & 1 & - & . & 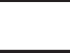 & \\
\hline $2 \mathrm{E}$ & & & & & & 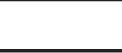 & & 3 & CS & $\mathrm{CS}$ & CS \\
\hline $2 \mathrm{~F}$ & . & & . & & & 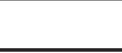 & & 2 & 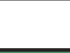 & 2 & \\
\hline $2 \mathrm{G}$ & 1 & 1 & 1 & & & 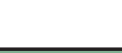 & & CS & 3 & $\mathrm{CS}$ & \\
\hline $2 \mathrm{H}_{2}$ & & & & & & CS & & 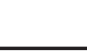 & 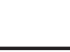 & 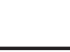 & \\
\hline $2 \mathrm{H} 3$ & & & & & & & & M & M & M & \\
\hline $3 A$ & & 3 & 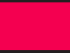 & & & - & & & & & \\
\hline $3 \mathrm{~B}$ & - & 2 & 2 & 2 & & 2 & & & & & \\
\hline $3 \mathrm{D}$ & 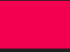 & & 2 & 1 & & 1 & & & & & \\
\hline $3 \mathrm{G}, \mathrm{H}, \mathrm{I}$ & 1 & 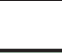 & . & & & & & & & & \\
\hline 3$\rfloor$ & & 2 & 2 & 2 & & & & & & & \\
\hline $4 \mathrm{~A}$ & CS & 2 & 2 & & & & & & & & \\
\hline $4 B$ & 2 & 2 & 2 & & & & & & & & \\
\hline $4 C$ & 2 & 2 & 2 & & & & & & & & \\
\hline 4D & 2 & 2 & 2 & & & & & & & & \\
\hline $4 \mathrm{E}$ & 2 & 2 & 2 & & & & & & & & \\
\hline $4 \mathrm{G}$ & CS & & & & & & & & & & \\
\hline $5 \mathrm{~A}$ & & 2 & . & & & & & & & & \\
\hline $5 \mathrm{~B} 1$ & & 2 & 2 & & & & 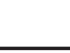 & & & & \\
\hline $5 \mathrm{~B} 2$ & & 2 & 2 & & & & & & & & \\
\hline $5 \mathrm{C}$ & & & & 1 & & 1 & 1 & & & & \\
\hline $5 \mathrm{D1}$ & & CS & CS & & & & & & & & \\
\hline $5 \mathrm{D} 2$ & & CS & CS & & & & & & & & \\
\hline $5 \mathrm{E}$ & & 2 & 2 & & & & & & & & \\
\hline
\end{tabular}

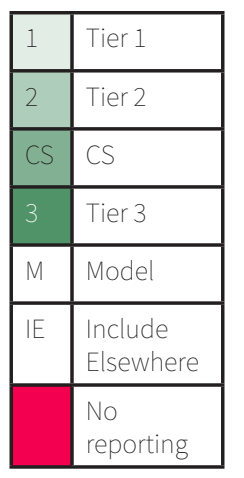




\section{Appendix 4: U.S. Methodology Choice}

Source: Prepared by the authors based on Inventory of U.S. Greenhouse Gas Emissions and Sinks 1990-2018 (EPA 2020)

\begin{tabular}{|c|c|c|c|c|c|c|c|c|c|}
\hline \multicolumn{10}{|c|}{ U.S. } \\
\hline & $\mathrm{CO}_{2}$ & $\mathrm{CH}_{4}$ & $\mathrm{~N}_{2} \mathrm{O}$ & $\mathrm{NO}_{\mathrm{x}}$ & $\mathrm{CO}$ & HFCS & $\mathrm{SF}_{6}$ & PFC & $\mathrm{NF}_{3}$ \\
\hline 1Ala & 2 & 1 & 1 & & & & & & \\
\hline $1 \mathrm{Alb}$ & 2 & 1 & 1 & & & & & & \\
\hline $1 \mathrm{AlC}$ & 2 & 1 & 1 & & & & & & \\
\hline $1 \mathrm{~A} 2 \mathrm{a}$ & 2 & 1 & 1 & & & & & & \\
\hline $1 \mathrm{~A} 2 \mathrm{~b}$ & 2 & 1 & 1 & & & & & & \\
\hline $1 \mathrm{~A} 2 \mathrm{C}$ & 2 & 1 & 1 & & & & & & \\
\hline $1 \mathrm{~A} 2 \mathrm{~d}$ & 2 & 1 & 1 & & & & & & \\
\hline $1 \mathrm{~A} 2 \mathrm{e}$ & 2 & 1 & 1 & & & & & & \\
\hline $1 \mathrm{~A} 2 \mathrm{f}$ & 2 & 1 & 1 & & & & & & \\
\hline $1 \mathrm{~A} 2 \mathrm{~g}$ & 2 & 1 & 1 & & & & & & \\
\hline $1 \mathrm{A3} a$ & 3 & 1 & 1 & & & & & & \\
\hline $1 \mathrm{~A} 3 \mathrm{~b}$ & 2 & 1 & 1 & & & & & & \\
\hline $1 \mathrm{~A} 3 \mathrm{C}$ & 2 & 1 & 1 & & & & & & \\
\hline 1A3d & 2 & 1 & 1 & & & & & & \\
\hline $1 \mathrm{A3e}$ & 2 & 1 & 1 & & & & & & \\
\hline $1 \mathrm{~A} 4$ & 2 & 1 & 1 & & & & & & \\
\hline 1A5a & $\mathrm{CS}$ & $M$ & $M$ & & & & & & \\
\hline $1 \mathrm{~A} 5 \mathrm{~b}$ & $\mathrm{CS}$ & $M$ & $M$ & & & & & & \\
\hline underground mining - hard coal & & 3 & & & & & & & \\
\hline Open-pit mining - lignite & & 2 & & & & & & & \\
\hline Solid fuel transformation & & 2 & . & & & & & & \\
\hline 1B2ai & CS & $\mathrm{CS}$ & $\mathrm{CS}$ & & & & & & \\
\hline 1B2aii & $\mathrm{CS}$ & $\mathrm{CS}$ & $\mathrm{CS}$ & & & & & & \\
\hline 1B2aiii & $\mathrm{CS}$ & CS & $\mathrm{CS}$ & & & & & & \\
\hline 1B2aiv & $\mathrm{CS}$ & $\mathrm{CS}$ & $\mathrm{CS}$ & & & & & & \\
\hline 1B2av & $\mathrm{CS}$ & CS & CS & & & & & & \\
\hline $1 \mathrm{~B} 2 \mathrm{bi}$ & CS & CS & $\mathrm{CS}$ & & & & & & \\
\hline 1B2bii & $\mathrm{CS}$ & CS & $\mathrm{CS}$ & & & & & & \\
\hline 1B2biii & $\mathrm{CS}$ & $\mathrm{CS}$ & $\mathrm{CS}$ & & & & & & \\
\hline 1B2biv(transmission) & $\mathrm{CS}$ & $\mathrm{CS}$ & CS & & & & & & \\
\hline 1B2biv(storage) & $\mathrm{CS}$ & $\mathrm{CS}$ & $\mathrm{CS}$ & & & & & & \\
\hline 1B2bv & $\mathrm{CS}$ & $\mathrm{CS}$ & $\mathrm{CS}$ & & & & & & \\
\hline 1B2bvi & $\mathrm{CS}$ & CS & $\mathrm{CS}$ & & & & & & \\
\hline $2 \mathrm{~A} 1$ & 2 & & & & & & & & \\
\hline $2 \mathrm{~A} 2$ & 2 & & & & & & & & \\
\hline $2 \mathrm{A3}$ & 3 & & & & & & & & \\
\hline $2 \mathrm{~A} 4 \mathrm{a}$ & 2 & & & & & & & & \\
\hline $2 \mathrm{~A} 4 \mathrm{~b}$ & 2 & & & & & & & & \\
\hline $2 \mathrm{~B} 1$ & CS & & & & & & & & \\
\hline
\end{tabular}

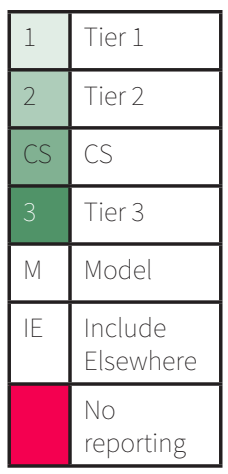




\begin{tabular}{|c|c|c|c|c|c|c|c|c|c|c|c|}
\hline \multicolumn{10}{|c|}{ U.S. } & & \\
\hline & $\mathrm{CO}_{2}$ & $\mathrm{CH}_{4}$ & $\mathrm{~N}_{2} \mathrm{O}$ & $\mathrm{NO}_{x}$ & $\mathrm{CO}$ & HFCS & $\mathrm{SF}_{6}$ & PFC & $\mathrm{NF}_{3}$ & & \\
\hline $2 \mathrm{~B} 2$ & & & 3 & & & & & & & & \\
\hline $2 \mathrm{~B} 3$ & & & 3 & & & & & & & 1 & Tier 1 \\
\hline $2 \mathrm{~B} 5$ & 1 & 1 & & & & & & & & 2 & Tier 2 \\
\hline $2 \mathrm{~B} 6$ & 1 & & & & & & & & & CS & $\mathrm{CS}$ \\
\hline $2 \mathrm{~B} 7$ & 1 & & & & & & & & & 3 & Tier 3 \\
\hline $2 \mathrm{~B} 8$ & 1 & 1 & & & & & & & & $M$ & Model \\
\hline $2 B 9$ & 3 & . & & & & & & & & $\overline{I E}$ & \begin{tabular}{|l} 
Include \\
\end{tabular} \\
\hline $2 \mathrm{Cl}$ & $\mathrm{CS}$ & CS & & & & & & & & & Elsewhere \\
\hline $2 \mathrm{C} 2$ & 1 & 1 & & & & & & & & & No \\
\hline $2 \mathrm{C} 3$ & $\mathrm{CS}$ & & & & & & & CS & & & reporting \\
\hline
\end{tabular}




\section{Appendix 5: Japan's Methodology Choice}

Source: Prepared by the authors based on National Greenhouse Gas Inventory Report of Japan (Greenhouse Gas Inventory Office of Japan 2020)

\begin{tabular}{|c|c|c|c|c|c|c|c|c|c|}
\hline \multicolumn{10}{|c|}{ Japan } \\
\hline & $\mathrm{CO}_{2}$ & $\mathrm{CH}_{4}$ & $\mathrm{~N}_{2} \mathrm{O}$ & HFCS & $\mathrm{SF}_{6}$ & PFC & $\mathrm{NF}_{3}$ & & \\
\hline $1 \mathrm{Ala}$ & 2 & 3 & 3 & & & & & 1 & Tier 1 \\
\hline $1 \mathrm{Alb}$ & 2 & 3 & 3 & & & & & 2 & Tier 2 \\
\hline 1AlC & 2 & 3 & 3 & & & & & c & CS \\
\hline $1 \mathrm{~A} 2 \mathrm{a}$ & 2 & 3 & 3 & & & & & 3 & Tier 3 \\
\hline $1 \mathrm{~A} 2 \mathrm{~b}$ & 2 & 3 & 3 & & & & & & Srd \\
\hline $1 \mathrm{~A} 2 \mathrm{C}$ & 2 & 3 & 3 & & & & & $N$ & Model \\
\hline $1 \mathrm{~A} 2 \mathrm{~d}$ & 2 & 3 & 3 & & & & & It & $\begin{array}{l}\text { Include } \\
\text { Elsewhere }\end{array}$ \\
\hline 1A2e & 2 & 3 & 3 & & & & & & \\
\hline $1 \mathrm{~A} 2 \mathrm{f}$ & 2 & 3 & 3 & & & & & & reporting \\
\hline
\end{tabular}

$1 \mathrm{~A} 2$

$1 \mathrm{A3}$

$1 \mathrm{~A} B \mathrm{~B}$

$1 \mathrm{ABC}$

$1 \mathrm{ABC}$

1A3e

$1 \mathrm{~A} 4$

$1 \mathrm{~A} 4 \mathrm{~b}$

$1 \mathrm{~A} 4 \mathrm{C}$

$1 \mathrm{~A} 5 \mathrm{C}$

1A5b

1B1

1B1aii

1B2ai

1B2aii

1B2aii

1B2aiv(refining)

1B2aiv(storage)

1B2av

1B2bi

1B2bi

1B2biii

1B2biv(trans-

portation)

1B2biv(storage

1B2bv

1B2bvi

$1 \mathrm{~B} 2 \mathrm{C}$

2A1 


\begin{tabular}{|c|c|c|c|c|c|c|c|c|c|}
\hline \multicolumn{10}{|c|}{ Japan } \\
\hline & $\mathrm{CO}_{2}$ & $\mathrm{CH}_{4}$ & $\mathrm{~N}_{2} \mathrm{O}$ & HFCs & $\mathrm{SF}_{6}$ & PFC & $\mathrm{NF}_{3}$ & & \\
\hline $2 \mathrm{~A} 2$ & 2 & & & & & & & 1 & Tier 1 \\
\hline $2 \mathrm{A3}$ & 2 & & & & & & & 2 & Tier 2 \\
\hline $2 \mathrm{~A} 4 \mathrm{a}$ & 2 & & & & & & & CS & CS \\
\hline $2 A 4 b$ & 2 & & & & & & & 3 & Tier 3 \\
\hline 2B1 & 3 & CS & 3 & 3 & 3 & 3 & 3 & & \\
\hline 2B2 & 3 & $\mathrm{CS}$ & 2 & 3 & 3 & 3 & 3 & tor & 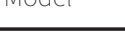 \\
\hline 2B3 & 3 & $\mathrm{CS}$ & 3 & 3 & 3 & 3 & 3 & IE & $\begin{array}{l}\text { Include } \\
\text { Elsewhere }\end{array}$ \\
\hline 2B4 & 3 & CS & 3 & 3 & 3 & 3 & 3 & & No \\
\hline $2 \mathrm{~B} 5 \mathrm{~b}$ & 2 & CS & 3 & 3 & 3 & 3 & 3 & & reporting \\
\hline
\end{tabular}



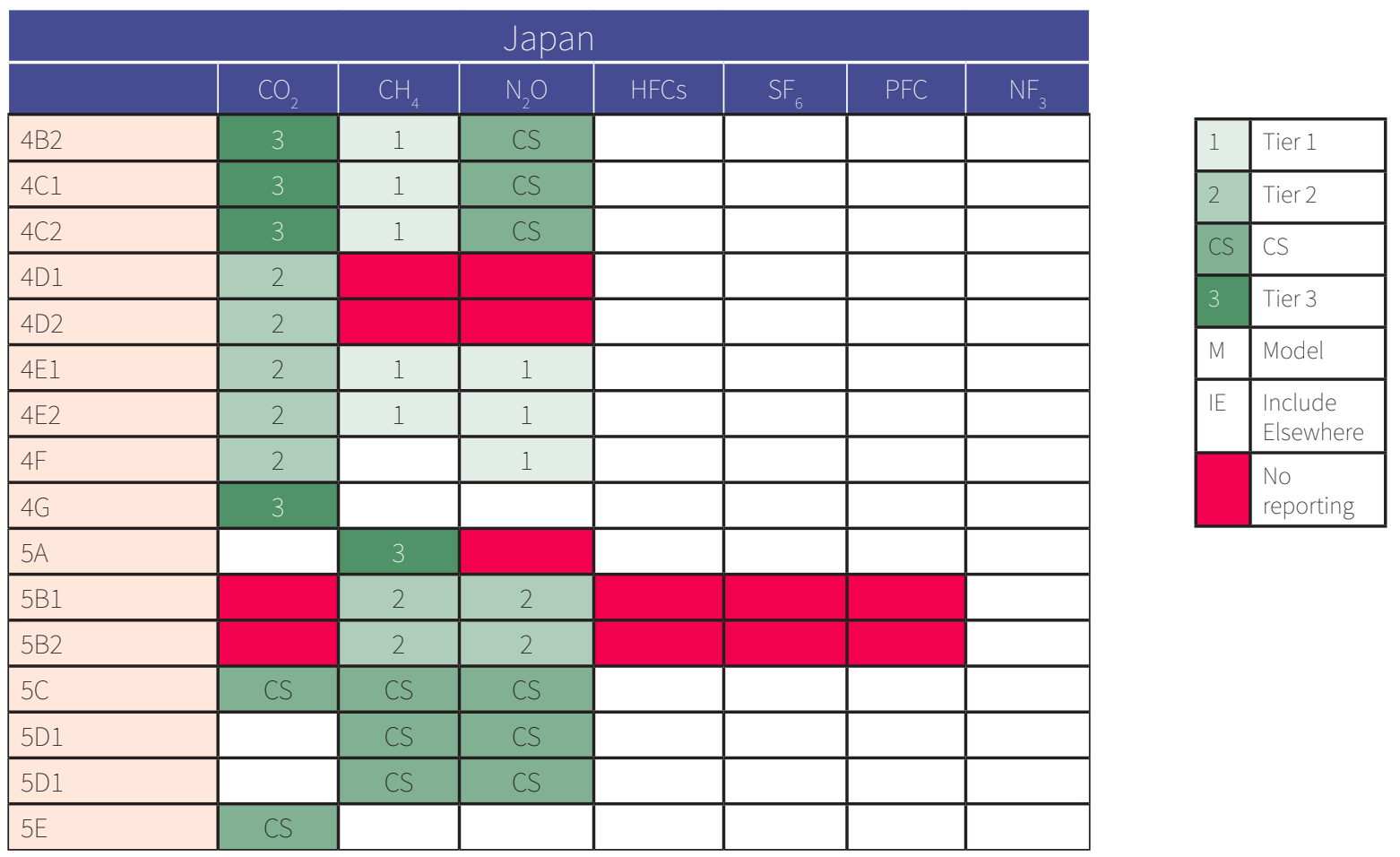

Appendix 6: Australia's Methodology Choice

Source: Prepared by the authors based on Department of Industry, Science, Energy and Resources (DISER 2020)

\begin{tabular}{|c|c|c|c|c|c|c|c|c|c|c|c|}
\hline \multicolumn{12}{|c|}{ Australia } \\
\hline & $\mathrm{CO}_{2}$ & $\mathrm{CH}_{4}$ & $\mathrm{~N}_{2} \mathrm{O}$ & $\mathrm{NO}_{\mathrm{r}}$ & $\mathrm{CO}$ & NMVOC & $\mathrm{SO}_{2}$ & HFCS & $\mathrm{SF}_{6}$ & PFC & $\mathrm{NF}_{3}$ \\
\hline 1Ala & 2 & 2 & 2 & & & & & & & & \\
\hline $1 \mathrm{Alb}$ & 2 & 2 & 2 & & & & & & & & \\
\hline $1 \mathrm{AlC}$ & 2 & 2 & 2 & & & & & & & & \\
\hline $1 \mathrm{~A} 2 \mathrm{a}$ & 2 & 2 & 2 & & & & & & & & \\
\hline $1 \mathrm{~A} 2 \mathrm{~b}$ & 2 & 2 & 2 & & & & & & & & \\
\hline $1 \mathrm{~A} 2 \mathrm{C}$ & 2 & 2 & 2 & & & & & & & & \\
\hline $1 \mathrm{~A} 2 \mathrm{~d}$ & 2 & 2 & 2 & & & & & & & & \\
\hline $1 \mathrm{~A} 2 \mathrm{e}$ & 2 & 2 & 2 & & & & & & & & \\
\hline $1 \mathrm{~A} 2 \mathrm{f}$ & 2 & 2 & 2 & & & & & & & & \\
\hline $1 \mathrm{~A} 2 \mathrm{~g}$ & 2 & 2 & 2 & & & & & & & & \\
\hline $1 \mathrm{A3a}$ & 2 & 2 & 2 & 1 & 1 & 1 & & & & & \\
\hline $1 \mathrm{~A} 3 \mathrm{~b}$ & 2 & 3 & 3 & & & & & & & & \\
\hline $1 \mathrm{~A} 3 \mathrm{C}$ & 2 & 1 & 1 & 2 & 2 & 2 & & & & & \\
\hline $1 \mathrm{~A} 3 \mathrm{~d}$ & 2 & 2 & 2 & & & & & & & & \\
\hline 1A3e & 2 & 1 & 1 & & & & & & & & \\
\hline $1 \mathrm{~A} 4 \mathrm{a}$ & 2 & 2 & 2 & & & & & & & & \\
\hline $1 \mathrm{~A} 4 \mathrm{~b}$ & 2 & 2 & 2 & & & & & & & & \\
\hline $1 \mathrm{~A} 4 \mathrm{C}$ & 2 & 2 & 2 & & & & & & & & \\
\hline $1 \mathrm{~A} 5 \mathrm{~b}$ & 1 & 2 & 2 & & & & & & & & \\
\hline 1Blai & 3 & 3 & & & & & & & & & \\
\hline
\end{tabular}

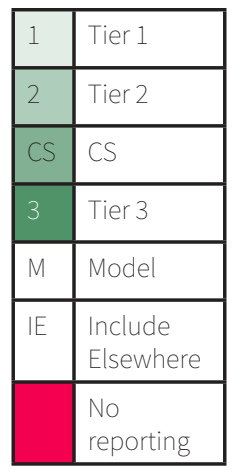




\begin{tabular}{|c|c|c|c|c|c|c|c|c|c|c|c|}
\hline \multicolumn{12}{|c|}{ Australia } \\
\hline & $\mathrm{CO}_{2}$ & $\mathrm{CH}_{4}$ & $\mathrm{~N}_{2} \mathrm{O}$ & $\mathrm{NO}_{\mathrm{x}}$ & $\mathrm{CO}$ & NMVOC & $\mathrm{SO}_{2}$ & HFCs & $\mathrm{SF}_{6}$ & PFC & $\mathrm{NF}_{3}$ \\
\hline 1Blaii & 3 & 3 & & & & & & & & & \\
\hline Post Mining & & 2 & & & & & & & & & \\
\hline $\begin{array}{l}\text { 1B1c(Decommissioned } \\
\text { mines) }\end{array}$ & & 3 & & & & & & & & & \\
\hline 1B1c(Flaring) & 2 & 2 & 2 & & & & & & & & \\
\hline 1B2ai & $\mathrm{CS}$ & $\mathrm{CS}$ & $\mathrm{CS}$ & & & & & & & & \\
\hline 1B2aii & $\mathrm{CS}$ & $\mathrm{CS}$ & $\mathrm{CS}$ & & & & & & & & \\
\hline 1B2aiii & $\mathrm{CS}$ & $\mathrm{CS}$ & $\mathrm{CS}$ & & & & & & & & \\
\hline 1B2aiv(refining) & $\mathrm{CS}$ & $\mathrm{CS}$ & $\mathrm{CS}$ & & & & & & & & \\
\hline 1B2aiv(storage) & $\mathrm{CS}$ & $\mathrm{CS}$ & $\mathrm{CS}$ & & & & & & & & \\
\hline 1B2av & CS & $\mathrm{CS}$ & $\overline{C S}$ & & & & & & & & \\
\hline 1B2avi & 1 & 1 & 1 & & & & & & & & \\
\hline 1B2bi & $\mathrm{CS}$ & $\mathrm{CS}$ & $\mathrm{CS}$ & & & & & & & & \\
\hline 1B2bii & $\mathrm{CS}$ & $\mathrm{CS}$ & $\mathrm{CS}$ & & & & & & & & \\
\hline 1B2biii & $\mathrm{CS}$ & $\mathrm{CS}$ & $\mathrm{CS}$ & & & & & & & & \\
\hline 1B2biv(transportation) & CS & $\mathrm{CS}$ & $\mathrm{CS}$ & & & & & & & & \\
\hline 1B2biv(storage) & $\mathrm{CS}$ & $\mathrm{CS}$ & $\mathrm{CS}$ & & & & & & & & \\
\hline $1 \mathrm{~B} 2 \mathrm{bv}$ & $\mathrm{CS}$ & $\mathrm{CS}$ & $\mathrm{CS}$ & & & & & & & & \\
\hline 1B2bvi & 1 & 1 & 1 & & & & & & & & \\
\hline $1 \mathrm{~B} 2 \mathrm{C}$ & 3 & 3 & 3 & & & & & & & & \\
\hline $2 \mathrm{~A} 1$ & 2 & & 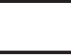 & & & & & & & & \\
\hline $2 \mathrm{~A} 2$ & 2 & & & & & & & & & & \\
\hline $2 \mathrm{A3}$ & 2 & & . & & & & & & & & \\
\hline $2 \mathrm{~A} 4 \mathrm{a}$ & 2 & & 7 & & & & & & & & \\
\hline $2 \mathrm{~A} 4 \mathrm{~b}$ & 2 & & . & & & & & & & & \\
\hline $2 \mathrm{~B} 1$ & 3 & & 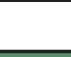 & & & & & & & & \\
\hline $2 \mathrm{~B} 2$ & 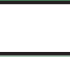 & & 3 & & & & & & & & \\
\hline $2 \mathrm{~B} 5$ & 2 & & & & & & & & & & \\
\hline $2 \mathrm{~B} 6$ & 2 & & & & & & & & & & \\
\hline $2 \mathrm{~B} 7$ & 3 & & & & & & & & & & \\
\hline $2 \mathrm{~B} 8$ & & 2 & & & & & & & & & \\
\hline $2 \mathrm{Cl}$ & 3 & 2 & 2 & & & & & & & & \\
\hline $2 \mathrm{C} 2$ & 2 & & - & & & & & & & & \\
\hline $2 \mathrm{C} 3$ & 3 & & & & & & & & & 3 & \\
\hline $2 \mathrm{C} 4$ & 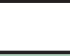 & & 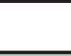 & & & & & & 2 & & \\
\hline $2 \mathrm{C5}$ & 2 & 2 & 2 & & & & & & & & \\
\hline $2 \mathrm{C6}$ & 2 & 2 & 2 & & & & & & & & \\
\hline $2 \mathrm{D} 7$ & 2 & 2 & 2 & & & & & & & & \\
\hline $2 \mathrm{D} 1$ & 2 & & & & & & & & & & \\
\hline $2 F$ & & & & & & & & $M$ & 2 & & \\
\hline $2 G$ & & & 2 & & & & & & & & \\
\hline $2 \mathrm{H} 2$ & $\mathrm{CS}$ & & & & & & & & & & \\
\hline $2 \mathrm{H3}$ & & & & & & & & & & & \\
\hline
\end{tabular}

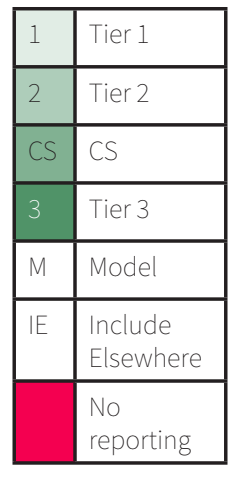




\begin{tabular}{|c|c|c|c|c|c|c|c|c|c|c|c|}
\hline \multicolumn{12}{|c|}{ Australia } \\
\hline & $\mathrm{CO}_{2}$ & $\mathrm{CH}_{4}$ & $\mathrm{~N}_{2} \mathrm{O}$ & $\mathrm{NO}_{\mathrm{x}}$ & $\mathrm{CO}$ & NMVOC & $\mathrm{SO}_{2}$ & HFCS & $\mathrm{SF}_{6}$ & PFC & $\mathrm{NF}_{3}$ \\
\hline $3 A 2,3$ & & $C S$ & & & & & & & & & \\
\hline $3 \mathrm{~A} 1$ & & $\mathrm{CS}$ & & & & & & & & & \\
\hline $3 A 4 b$ & & 1 & & & & & & & & & \\
\hline $3 \mathrm{~B} 1,3$ & & $\mathrm{CS}$ & $\mathrm{CS}$ & & & & & & & & \\
\hline $3 \mathrm{~B} 2,4$ & & CS & CS & & & & & & & & \\
\hline $3 \mathrm{~B} 5$ & & & $\mathrm{CS}$ & & & & & & & & \\
\hline $3 C$ & & 1 & 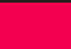 & & & & & & & & \\
\hline 3D1a,b,c,e,f,g & & & 2 & & & & & & & & \\
\hline $3 \mathrm{D} 1 \mathrm{~h}$ & & & 1 & & & & & & & & \\
\hline $3 \mathrm{D} 2 \mathrm{a}$ & & & 1 & & & & & & & & \\
\hline $3 \mathrm{D} 2 \mathrm{~b}$ & & - & $\mathrm{CS}$ & & & & & & & & \\
\hline $3 G$ & & $\mathrm{CS}$ & & & & & & & & & \\
\hline $3 \mathrm{H}$ & & 1 & & & & & & & & & \\
\hline $3 F$ & & $\mathrm{CS}$ & $\mathrm{CS}$ & & & & & & & & \\
\hline $4 \mathrm{~A} 1$ & 3 & & & & & & & & & & \\
\hline $4 \mathrm{~A} 2$ & 3 & & & & & & & & & & \\
\hline $4 \mathrm{~B} 1$ & 3 & & & & & & & & & & \\
\hline 4B2 & 3 & & & & & & & & & & \\
\hline $4 \mathrm{Cl}$ & 3 & & & & & & & & & & \\
\hline $4 C 2$ & 3 & & & & & & & & & & \\
\hline $4 \mathrm{D} 1$ & 2 & 2 & 2 & & & & & & & & \\
\hline $4 \mathrm{D} 2$ & 3 & 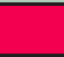 & 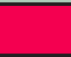 & & & & & & & & \\
\hline $4 \mathrm{E} 1$ & 2 & 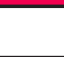 & & & & & & & & & \\
\hline $4 \mathrm{E} 2$ & 3 & & & & & & & & & & \\
\hline $4 G$ & 3 & 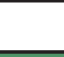 & $\mathrm{CS}$ & & & & & & & & \\
\hline $5 A$ & & 3 & 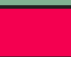 & & & & & & & & \\
\hline $5 \mathrm{~B} 1$ & & 1 & 1 & & & & & & & & \\
\hline $5 B 2$ & & 1 & 1 & & & & & & & & \\
\hline $5 C$ & 2 & 2 & 2 & & & & & & & & \\
\hline $5 \mathrm{D} 1$ & & 3 & $\mathrm{CS}$ & & & & & & & & \\
\hline $5 \mathrm{D} 1$ & & 3 & CS & & & & & & & & \\
\hline
\end{tabular}

\begin{tabular}{|l|l|}
\hline 1 & Tier 1 \\
\hline 2 & Tier 2 \\
\hline CS & CS \\
\hline 3 & Tier 3 \\
\hline M & Model \\
\hline IE & $\begin{array}{l}\text { Include } \\
\text { Elsewhere }\end{array}$ \\
\hline & $\begin{array}{l}\text { No } \\
\text { reporting }\end{array}$ \\
\hline
\end{tabular}




\section{References}

Australian Government, Department of Industry, Science, Energy and Resources (DISER), National Inventory Report 2018. Commonwealth of Australia, May 2020, https://www.industry.gov.au/sites/default/files/2020-05/ nga-national-inventory-report-2018-volume-1.pdf.

Federal Republic of Germany, 2020 National Inventory Report. United Nations Framework Convention on Climate Change, 2020, https://unfccc.int/documents/226313.

Greenhouse Gas Inventory Office of Japan, National Greenhouse Gas Inventory Report of Japan. Japan: Center for Global Environmental Research, National Institute for Environmental Studies, 2020, https://www.nies.go.jp/gio/ archive/nir/jajm1000000pcibe-att/NIR-JPN-2020-v3.0 GIOweb.pdf.

Intergovernmental Panel on Climate Change (IPCC), 2006 IPCC Guidelines for National Greenhouse Gas Inventories - A primer. Hamaya, Japan: Institute for Global Environmental Strategies, 2008, https://www.ipcc-nggip.iges. or.jp/support/Primer 2006GLs.pdf.

Intergovernmental Panel on Climate Change (IPCC), 2019 Refinement to the 2006 IPCC Guidelines for National Greenhouse Gas Inventories. 2019, https://www.ipcc.ch/report/2019-refinement-to-the-2006-ipcc-guidelinesfor-national-greenhouse-gas-inventories.

Juhrich, Kristina, Emission Factors for Fossil Fuels in Germany. Germany: $15^{\text {th }}$ Expert Meeting on Data for the IPCC Emissions Factor Database (EFDB), 2017, https://iea.blob.core.windows.net/assets/imports/events/243/13 Germany K.Juhrich.pdf.

Kainou, Kazunari, Recommendation of Draft Revised Standard Calorific Value and Carbon Emission Factor for Fossil Fuel Energy Sources in Japan. Japan: Research Institute of Economy, Trade and Industry, January 2016, https://www.rieti.go.jp/users/kainou-kazunari/14j047 e.pdf.

People's Republic of China (PRC), The People's Republic of China Second Biennial Update Report on Climate Change. United Nations Framework Convention on Climate Change, December 2018, https://unfccc.int/sites/ default/files/resource/China\%202BUR English.pdf.

Romijn, Erika, Martin Herold, Lammert Kooistra, Daniel Murdiyarso, and Louis Verchot, "Assessing capacities of non-Annex I countries for national forest monitoring in the context of REDD+." Environmental Science \& Policy, vol. 19-20 (May-June 2012): 33-48.

United Nations Framework Convention on Climate Change, Biennial Update Report submissions from Non-Annex I Parties. 2020, https://unfccc.int/BURs.

United States Environmental Protection Agency (EPA), Inventory of U.S. Greenhouse Gas Emissions and Sinks 1990-2019. United States, 2020, https://www.epa.gov/sites/production/files/2021-04/documents/us-ghginventory-2021-main-text.pdf.

Winkler, Harald, Brian Mantlana, and Thapelo Letete, "Transparency of action and support in the Paris Agreement." Climate Policy, vol. 17, no. 7 (2017): 853-872, https://sciencepolicy.colorado.edu/students/envsgeog 3022/winkler 2017.pdf. 


\section{COMII}

The Coalition on Materials Emissions Transparency (COMET) is an initiative between the Columbia Center on Sustainable Investment (CCSI), the Payne Institute for Public Policy at the Colorado School of Mines, and RMI.

Design: Michael Morgan
COMET accelerates supply chain decarbonization by enabling producers, consumer-facing companies, investors, and policy makers to better account for greenhouse gas (GHG) emissions throughout materials supply chains, in harmony with existing GHG accounting and disclosure methods and platforms. cometframework.org 